\title{
The association of lipophilic phospholipids with native bovine casein micelles in skim milk: Effect of lactation stage and casein micelle size
}

\author{
M. Cheema, ${ }^{*}$ P. B. Smith, † A. D. Patterson, $\ddagger$ A. Hristov, $\S$ and F. M. Harte ${ }^{\star 1}$ \\ *Department of Food Science, \\ †The Huck Institutes of the Life Sciences, \\ łDepartment of Veterinary and Biomedical Sciences, and \\ §Department of Animal Science, The Pennsylvania State University, University Park 16802
}

\begin{abstract}
A known biological role of casein micelles is to transport calcium from mother to young and provide amino acids for growth and development. Previous reports demonstrated that modified casein micelles can be used to transport and deliver hydrophobic probes. In this study, the distribution of lipid-soluble phospholipids, including sphingomyelins (SM) and phosphatidylcholines (PC), was quantified in whole raw milk, skim raw milk, and casein micelles of various sizes during early, mid, and late lactation stages. Low-pressure size exclusion chromatography was used to separate casein micelles by size, followed by hydrophobic extraction and liquid chromatography-mass spectrometry for the quantification of PC and SM. Results showed that the SM d18: 1/23:0, d18:1/22:0, d18:1/16:0, d16:1/22:0, d16:1/23:0, and d18:1/24:0 and the PC 16:0/18:1, 18:0/18:2, and 16:0/16:0 were dominating candidates appearing in maximum concentration in whole raw milk obtained from late lactation, with 21 to $50 \%$ of total SM and 16 to $35 \%$ of total PC appearing in skim milk. Of the total $\mathrm{SM}$ and PC found in skim milk, 35 to $46 \%$ of SM and 22 to $29 \%$ of PC were associated with the casein micelle fraction. The highest concentrations of SM d18:1/22: $0(341 \pm 17 \mu \mathrm{g} / \mathrm{g}$ of casein protein) and PC 16:0/18:1 $(180 \pm 20 \mu \mathrm{g} / \mathrm{g}$ of casein protein) were found to be associated with the largest casein micelles (diameter $=$ $149 \mathrm{~nm}$ ) isolated in milk from late lactation, followed by a decrease in concentration as the casein micelle size decreased.
\end{abstract}

Key words: casein micelle, lipophilic, phospholipid, sphingomyelin, phosphatidylcholine

Received November 14, 2017.

Accepted May 4, 2018.

${ }^{1}$ Corresponding author: fede@psu.edu

\section{INTRODUCTION}

Bovine milk contains approximately $3.3 \%$ (wt/wt) protein, and casein proteins account for approximately $80 \%$ of the total protein content in bovine milk. Casein proteins exist as colloidal particles known as casein micelles, comprising 4 major casein proteins: $\alpha_{\mathrm{S}^{-}}, \alpha_{\mathrm{S}^{-}}, \beta-$, and $\kappa$-casein in an approximate ratio of 4:1:3.5:1.5 (Farrell et al., 2004). Although the casein micelle structure is still under investigation, it is known that $\kappa$-casein is predominantly present on the surface of the casein micelle, imparting stability against micellar aggregation by electrostatic and steric repulsion, whereas $\alpha_{\mathrm{S1}^{-}}$, $\alpha_{S_{2}-}$, and $\beta$-caseins are predominantly present inside the core of the casein micelle (Dalgleish, 2011; de Kruif et al., 2012; Holt et al., 2013). Modified casein micelles were used to encapsulate and deliver several hydrophobic probes, including vitamin A (Mohan et al., 2013), vitamin D (Semo et al., 2007), curcumin (Sahu et al., 2008), triclosan (Roach et al., 2009), and docosahexaenoic acid (Zimet et al., 2011). It is not known whether the ability of modified casein micelles to associate with hydrophobic probes is derived from their native preference to bind hydrophobic compounds in milk.

Lipophilic phospholipids (PL), including sphingomyelins (SM) and phosphatidylcholines (PC), are a major source of choline and are important for neurological development in infants (Tanaka et al., 2013). Choline is needed for infant organ growth and membrane biosynthesis, therefore rendering PL as significant ingredients in infant formula (Holmes-McNary et al., 1996; Caudill, 2010). Sphingomyelins and PC account for approximately 30 and $34 \%$ of total phospholipids in whole bovine milk, respectively. Although polar phospholipids are known components of the milk fat globule membrane (MFGM), approximately $60 \%$ of the total phospholipids have been found in skim milk after removal of fat, with PC and SM constituting approximately 31 and $29 \%$ of total PL content, respectively (Christie et al., 1987). Zeisel et al. (2003) found $0.71 \mathrm{mg}$ of SM/100 
$\mathrm{g}$ of commercial skim milk versus $0.65 \mathrm{mg}$ of $\mathrm{SM} / 100$ $\mathrm{g}$ of whole milk and $0.75 \mathrm{mg}$ of $\mathrm{PC} / 100 \mathrm{~g}$ of skim milk versus $0.61 \mathrm{mg}$ of $\mathrm{PC} / 100 \mathrm{~g}$ of whole milk despite their low solubility in water. Various factors may explain these differences. For instance, it was demonstrated that the concentration of individual PC in whole milk changes with lactation stage (Artegoitia et al., 2014).

The hypothesis driving the current study was that the open structure of the native casein micelle allows for the association of small PL to micellar hydrophobic regions. In our previous study, we showed that highly lipophilic PC and SM $(\log P>10 ; \log \mathrm{P}$ is logarithm of the partition between octanol and water) were found to be associated with casein micelles in bovine skim raw milk (Cheema et al., 2015). However, the partitioning of individual PC and SM into casein micelles and the effect of casein micelle size were not previously studied. The relative ratio of each casein protein changes with micelle size, with comparatively smaller micelles containing higher $\kappa$-casein and lower $\beta$-casein relative content and $\alpha_{\mathrm{S1}^{-}}$and $\alpha_{\mathrm{S} 2^{-}}$casein remaining constant (Dalgleish et al., 1989). Hydrophobic domains in $\beta$-caseins are known to play a role in interacting with hydrophobic compounds, and smaller casein micelles are expected to have fewer sites available for binding hydrophobic compounds, partially due to decreasing $\beta$-casein content.

The objective of this study was to demonstrate that the casein micelles are reservoirs for SM and $\mathrm{PC}$ in commercial skim milk. Additionally, we sought to determine whether micellar size and stage of lactation influenced the association of SM and PC with casein micelles.

\section{MATERIALS AND METHODS}

\section{Milk Sample Collection and Preparation}

Raw milk samples were collected from a total of 9 Holstein cows, 3 cows per lactation stage (early, mid, and late), from The Pennsylvania State University Research and Teaching Dairy Center (University Park). The raw milk samples were collected from first-parity cows with low $\mathrm{SCC}\left(<5 \times 10^{4} \mathrm{SCC} / \mathrm{mL}\right)$ and average $\mathrm{BW}$ of $580 \pm 30 \mathrm{~kg}$ in early lactation $(\mathrm{DIM}=21$ ), $607 \pm 70 \mathrm{~kg}$ in mid lactation $(\mathrm{DIM}=91)$, and 630 $\pm 35 \mathrm{~kg}$ in late lactation (DIM $=217)$. The milk was transported on ice and stored at $4^{\circ} \mathrm{C}$ until analysis. The skim milk samples were generated by removing fat using centrifugation at $20^{\circ} \mathrm{C}(6,414 \times g$ for $20 \mathrm{~min})$ and stored at $4^{\circ} \mathrm{C}$ until fractionation of casein micelles using size exclusion low-pressure chromatography (SEC).

\section{SEC}

Samples of skim raw milk ( $5 \mathrm{~mL}$ ) were subjected to fractionation into casein micelles of varying sizes by using a XK 26/100 (mm/cm) column packed with Sephacryl medium (S-1000, GE Life Sciences, Piscataway, NJ) connected to an AKTA 150 fast performance chromatography unit (GE Life Sciences). The mobile phase consisted of $20 \mathrm{~m} M$ imidazole buffer, $10 \mathrm{mM}$ calcium chloride, and $0.07 \%$ sodium azide $\left(\mathrm{NaN}_{3}\right.$; Fisher Scientific, Fair Lawn, NJ) with pH adjusted to 6.8. The buffer was empirically shown to maintain the integrity of the casein micelles in milk's physiological $\mathrm{pH}$ of 6.6 to 6.8. The column was equilibrated for 2 column volumes $(956 \mathrm{~mL})$. The proteins were eluted at a flow rate of $1.0 \mathrm{~mL} / \mathrm{min}$ for 1.5 column volumes $(717 \mathrm{~mL})$ by collecting $30 \mathrm{~mL}$ of each fraction. The protein elution was monitored at a $280-\mathrm{nm}$ wavelength. Five fractions of casein micelles of varying sizes were collected and verified by SDS-PAGE. A total of $200 \mu \mathrm{L}$ of volume of each fraction was saved for particle size analysis and casein protein content analysis. The remaining fractions were freeze-dried and stored at $-20^{\circ} \mathrm{C}$ until extractions were performed.

\section{SDS-PAGE}

The 5 SEC fractions $\left(2 \mathrm{~A}_{1}, 2 \mathrm{~A}_{2}, 2 \mathrm{~A}_{3}, 2 \mathrm{~B}_{1}\right.$, and $2 \mathrm{~B}_{2}$; see Figure 1) were freeze-dried and subjected to SDSPAGE to confirm the presence of casein proteins. All reagents and precast gels for SDS-PAGE gel electrophoresis were purchased from Bio-Rad Laboratories (Hercules, CA). The SDS-PAGE electrophoresis of all 5 casein fractions was performed under denaturing and reducing conditions. The loading buffer was prepared using $0.5 M$ Tris- $\mathrm{HCl}$ (pH 6.8), glycerol, $10 \%$ (wt/vol) SDS, $\beta$-mercaptoethanol, and $0.5 \%$ (wt/vol) bromophenol blue in water. The freeze-dried samples (5 mg) were suspended in $500 \mu \mathrm{L}$ of loading buffer followed by heating to $95^{\circ} \mathrm{C}$ for $5 \mathrm{~min}$ before electrophoresis in $15 \%$ polyacrylamide SDS-PAGE ready gels. The gel electrophoresis was performed by loading $15 \mu \mathrm{L}$ of sample in each well. The gels were run at a constant $200 \mathrm{~V}$ for $35 \mathrm{~min}$. The protein bands were silver stained following the manufacturer's protocol (Silver Stain Plus, Bio-Rad Laboratories).

\section{Particle Size Analysis}

The particle size of the 5 fractions collected from SEC was determined by dynamic light scattering using a Viscotek 802 DLS instrument equipped with Omni- 

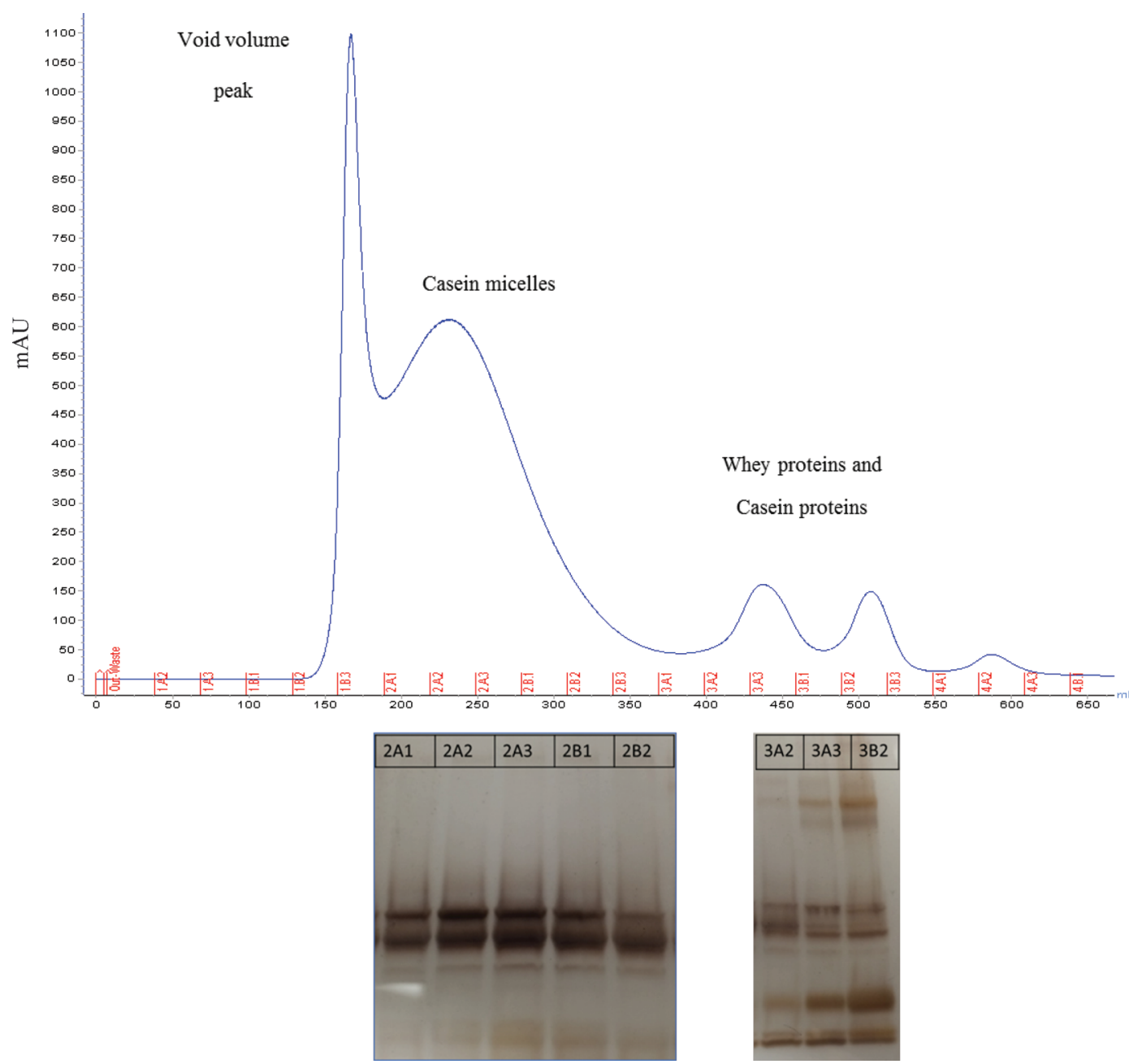

Figure 1. Representative size exclusion chromatography chromatogram with SDS-PAGE gel electrophoresis of the corresponding casein fractions isolated from bovine skim raw milk. Color version available online.

SIZE software (Malvern Instruments, Pittsburgh, PA). Optimized concentration of solutions was obtained by diluting with $20 \mathrm{~m} M$ imidazole buffer and $10 \mathrm{~m} M \mathrm{CaCl}_{2}$ (pH 6.8). The particle size was determined 3 times for each replication.

\section{Fraction Casein Content Analysis}

The protein content of each of the 5 casein fractions isolated from skim raw milk using SEC was quantified using the Bradford assay with sodium caseinate as a calibration standard (Bradford, 1976). Two milliliters of the Bradford reagent (Coomassie Brilliant Blue G-250 dye, Bio-Rad Laboratories) was added to 100 $\mu \mathrm{L}$ of each casein fraction, and absorbance measurements were made after equilibrating the samples for 10 min using a spectrophotometer set at $595 \mathrm{~nm}$ (10S UV-Vis Genesys, Thermo-Scientific, Waltham, MA).
The analysis was completed in triplicate for each casein micelle size and treatment replication.

\section{Sample Extraction for PL}

The lipophilic polar phospholipids, PC, lyso-PC, and SM were extracted using a method developed by Bligh and Dyer (1959). The whole raw milk $(200 \mu \mathrm{L})$ and skim raw milk $(200 \mu \mathrm{L})$ samples were extracted using $1 \mathrm{~mL}$ of the extraction solvent (chloroform, methanol, and water at a 1:2:0.8 ratio) followed by vortexing and centrifugation at $16,000 \times g$ for $5 \mathrm{~min}$ at room temperature (Microfuge 16, Beckman Coulter, Indianapolis, IN). The supernatant was transferred to a separate glass vial followed by repetition of the extraction procedure twice. Each time, the resultant supernatant was transferred into the same glass vial. The combined supernatant was dried under a nitrogen stream, dis- 
solved in $1 \mathrm{~mL}$ of methanol, and subjected to analysis using liquid chromatography-tandem MS (LC-MS/ MS). The freeze-dried casein fractions of 5 different sizes $\left(2 \mathrm{~A}_{1}, 2 \mathrm{~A}_{2}, 2 \mathrm{~A}_{3}, 2 \mathrm{~B}_{1}\right.$, and $\left.2 \mathrm{~B}_{2}\right)$ obtained from $5-\mathrm{mL}$ skim raw milk samples by SEC were extracted using the above method as well. A total of $500 \mu \mathrm{L}$ of each sample was spiked with $40 \mu \mathrm{L}$ of $0.1 \mathrm{mg} / \mathrm{mL}$ of the internal standards (PC 17:0/17:0 and SM 18:1/12:0; Avanti Polar Lipids, Alabaster, AL). The standards were selected based on the negligible concentration of odd-chain-length PC (C17:0; $<0.6 \%$ in whole raw milk) and small-carbon-chain SM (C12:0; not detected) in bovine milk as previously reported (Fong et al., 2007). Preliminary analysis of samples with and without internal standards was done to confirm the absence of measurable concentrations of internal standards.

\section{LC-MS/MS Analysis for PL}

The LC-MS/MS analysis was performed using a Prominence UFLC-XR (Shimadzu, Columbia, MD) followed by a quadrupole time-of-flight mass spectrometer (AB Sciex 5600, Sciex, Framingham, MA). The analysis of PL (PC and SM) was done by injecting $5 \mu \mathrm{L}$ of each extracted sample onto a BEH C18 column (100 $\times 2.1 \mathrm{~mm}, 1.7 \mu M$; Waters, Milford, MA). The mobile phase comprised solvent A (60\% acetonitrile with $40 \%$ water, $10 \mathrm{~m} M$ ammonium formate, $0.1 \%$ formic acid) and solvent B (90\% isopropanol, $10 \%$ acetonitrile, 10 $\mathrm{m} M$ ammonium acetate, $0.1 \%$ formic acid). A gradient dilution was used for 20 min as follows: $40 \%$ B was held for 0:01 min:s, increased to $43 \% \mathrm{~B}$ at 2:00 min:s, increased to $50 \% \mathrm{~B}$ at 2:10 min:s, increased to $54 \%$ $\mathrm{B}$ at 12:00 min:s, increased to $70 \% \mathrm{~B}$ at $12: 10 \mathrm{~min}: \mathrm{s}$, increased to $99 \%$ B at 18:00 min:s, held at 99\% B up to $20 \mathrm{~min}$, and decreased to $40 \% \mathrm{~B}$ at 20:10 min:s with a flow rate of $0.225 \mathrm{~mL} / \mathrm{min}$. The analysis for $\mathrm{PC}$ and $\mathrm{SM}$ was performed in positive mode. The positive ion electrospray ionization mass spectra were obtained over a mass range of 100 to 1,200 mass:charge ratio $(\boldsymbol{m} / \boldsymbol{z})$ in an information-dependent acquisition mode with one 100-ms survey scan and up to twenty 100-ms MS/MS product ion scans per duty cycle. Three determinations were done for each replicate.

\section{Data Analysis}

The PeakView software (Sciex) was used to identify the PC and SM candidates based on the mass fragments of fatty acid (FA) chain lengths obtained from MS/MS data. The peak areas were obtained by extracting the specific $m / z$ values using the same software. The statistical differences were evaluated by ANOVA followed by Tukey's honest significant difference test $(P<0.05)$. Data were analyzed using SAS (version 9.4; SAS Institute Inc., Cary, NC). Average values were calculated using 3 true replications in early, mid, and late lactation samples. Linear and quadratic orthogonal polynomials were used to determine the significance of SM and PC micellar concentration as a function of diameter.

\section{RESULTS AND DISCUSSION}

\section{SEC}

A representative chromatogram obtained from SEC of $5 \mathrm{~mL}$ of skim raw milk shows the milk proteins separated in order of decreasing size (Figure 1). The casein micelle fractions from the first peak were collected as $2 \mathrm{~A}_{1}, 2 \mathrm{~A}_{2}, 2 \mathrm{~A}_{3}, 2 \mathrm{~B}_{1}$, and $2 \mathrm{~B}_{2}$, and casein protein content was confirmed by SDS-PAGE gel electrophoresis. Fraction $1 \mathrm{~B}_{3}$ was not included for further analysis as contents were collected in the void volume of the column (i.e., outside the resolution of the Sephacryl S-1000 medium). The strong absorbance of peak $1 \mathrm{~B}_{3}$ was probably the result of a combination of large protein aggregates and bacterial or somatic cells. Fractions $3 \mathrm{~A}_{2}, 3 \mathrm{~A}_{3}$, and $3 \mathrm{~B}_{2}$ containing coeluted monomeric casein and whey proteins $(\beta-\mathrm{LG}, \alpha-\mathrm{LA})$ as shown in SDS-PAGE were excluded from further analysis. Fractions $2 \mathrm{~A}_{1}, 2 \mathrm{~A}_{2}, 2 \mathrm{~A}_{3}$, $2 \mathrm{~B}_{1}$, and $2 \mathrm{~B}_{2}$ (Figure 1) were freeze-dried and stored at $-20^{\circ} \mathrm{C}$ until further particle size and protein analysis and extraction.

\section{Particle Size and Casein Protein Analysis}

Fractions $2 \mathrm{~A}_{1}, 2 \mathrm{~A}_{2}, 2 \mathrm{~A}_{3}, 2 \mathrm{~B}_{1}$, and $2 \mathrm{~B}_{2}$ collected from early, mid, and late lactation stages showed average hydrodynamic diameter ranging from $149 \pm 2.8 \mathrm{~nm}$ $($ mean $\pm \mathrm{SE})$ to $87 \pm 1.5 \mathrm{~nm}$ (Table 1$)$, consistent with previous reports. The casein protein content was calculated by combining the amounts of casein protein quantified in the 5 fractions using the Bradford assay. The protein content of the 5 fractions obtained by SEC of 5-mL raw skim milk samples from 3 lactation stages showed that the casein protein content ranged from $326.2 \pm 2.8 \mathrm{mg} / 100 \mathrm{~mL}$ of skim milk (mean $\pm \mathrm{SE}$ ) to $187.7 \pm 7.2 \mathrm{mg} / 100 \mathrm{~mL}$ from the largest to smallest casein protein fraction in milk from early lactation, $427.3 \pm 10.0 \mathrm{mg} / 100 \mathrm{~mL}$ to $260.9 \pm 1.1 \mathrm{mg} / 100 \mathrm{~mL}$ in milk from mid lactation, and $297.2 \pm 2.6 \mathrm{mg} / 100 \mathrm{~mL}$ to $224.2 \pm 2.6 \mathrm{mg} / 100 \mathrm{~mL}$ in milk from late lactation (Table 1). Our observations were consistent with previous studies reporting maximum concentration of casein protein in mid lactation (Ostersen et al., 1997). 
Table 1. Casein protein content in size exclusion chromatography (SEC) fractions of early, mid, and late lactations

\begin{tabular}{lcccc}
\hline & & \multicolumn{3}{c}{ Casein protein $^{2}(\mathrm{mg} / 100 \mathrm{~mL})$} \\
\cline { 3 - 5 } $\begin{array}{l}\text { Casein fraction } \\
\text { SEC })\end{array}$ & $\begin{array}{c}\text { Casein micelle } \\
\text { diameter }^{1}(\mathrm{~nm})\end{array}$ & Early & Mid & Late \\
\hline $2 \mathrm{~A}_{1}$ & $149 \pm 2.8^{\mathrm{A}}$ & $326.2 \pm 2.8^{\mathrm{b}}$ & $427.3 \pm 9.9^{\mathrm{a}}$ & $297.2 \pm 2.6^{\mathrm{c}}$ \\
$2 \mathrm{~A}_{2}$ & $125 \pm 0.9^{\mathrm{B}}$ & $348.9 \pm 8.5^{\mathrm{b}}$ & $508.1 \pm 15.9^{\mathrm{a}}$ & $396.9 \pm 14.8^{\mathrm{b}}$ \\
$2 \mathrm{~A}_{3}$ & $107 \pm 0.9^{\mathrm{C}}$ & $280.9 \pm 0.5^{\mathrm{c}}$ & $465.2 \pm 7.4^{\mathrm{a}}$ & $423.1 \pm 3.0^{\mathrm{b}}$ \\
$2 \mathrm{~B}_{1}$ & $95 \pm 1.5^{\mathrm{D}}$ & $232.3 \pm 6.3^{\mathrm{b}}$ & $307.3 \pm 2.9^{\mathrm{a}}$ & $321.1 \pm 8.8^{\mathrm{a}}$ \\
$2 \mathrm{~B}_{2}$ & $87 \pm 1.5^{\mathrm{E}}$ & $187.7 \pm 7.2^{\mathrm{c}}$ & $260.9 \pm 1.1^{\mathrm{a}}$ & $224.2 \pm 2.6^{\mathrm{b}}$ \\
\hline
\end{tabular}

${ }^{\mathrm{A}-\mathrm{E}}$ Means within a column with the same uppercase superscript do not differ $(P<0.05)$.

${ }^{\mathrm{a}-\mathrm{c}}$ Means within a row with the same lowercase superscript do not differ $(P<0.05)$.

${ }^{1}$ Average for early, mid, and late; values are means $\pm \mathrm{SE}(\mathrm{n}=9)$.

${ }^{2}$ Values are means $\pm \mathrm{SE}(\mathrm{n}=3)$.

\section{LC-MS/MS Analysis for PL}

Characterization of $S M$ and $P C$ in Bovine Milk. The raw milk from each of the 3 lactation stages (early, mid, and late) showed specific SM and PC profiles. The FA composition of SM and PC candidates was identified based on the fragments obtained from their MS/MS data. A total of 16 lipophilic SM with partition coefficient values $\left(\log \mathrm{P}_{\text {octanol/water }}\right.$ ) ranging from 11.2 to 16.6 were identified based on the online databases LIPID MAPS (http://www.lipidmaps.org/ data/structure/) and PubChem (https://pubchem.ncbi .nlm.nih.gov; Table 2).

The SM structure is a ceramide consisting of a long chain base (LCB) and an FA chain without the phosphocholine group as shown in Figure 2. The dominant product ion for SM shows up as $m / z 184$, corresponding to the protonated phosphocholine head group.
The protonated molecular ion $[\mathrm{M}+\mathrm{H}]^{+}$represents the parent peak. The FA chains and LCB were identified by analyzing their respective MS/MS spectra, which shows the major product ions corresponding to the fragments of protonated ceramide, by losing 1 or 2 molecules of water-that is, [Ceramide- $\left.\mathrm{H}_{2} \mathrm{O}+\mathrm{H}\right]^{+}$ and $\left[\text { Ceramide- } 2 \mathrm{H}_{2} \mathrm{O}+\mathrm{H}\right]^{+}$, respectively. The other product ions used to identify the composition of SM were referred to as the protonated long-chain FA fragment $\left([\mathbf{F A}(\mathbf{L})]^{+}\right)$and the short-chain FA fragment $\left([\mathbf{F A}(\mathrm{S})]^{+}\right)$. The $[\mathrm{FA}(\mathrm{L})]^{+}$and $[\mathrm{FA}(\mathrm{S})]^{+}$refer to the FA chain fragments generated by the fragmentation of the FA at the specific bonds as shown in Figure 2. The masses of FA and LCB fragments were identified by comparing with the SM database. The protonated molecular ion $m / z[\mathrm{M}+\mathrm{H}]^{+} 761.7$ was identified with LCB as d16:0 and FA chain C22:0. The presence of a protonated phosphocholine fragment at $\mathrm{m} / z 184$ along

Table 2. Identification of specific fatty acyl chains of sphingomyelin $\left.(\mathrm{SM} ; \mathrm{M}+\mathrm{H}]^{+}\right)$in bovine milk

\begin{tabular}{lllrl}
\hline Ion $(m / z)^{1}$ & Fatty acid & $\begin{array}{l}\text { Molecular } \\
\text { formula }\end{array}$ & $\begin{array}{c}\text { Log } \\
P \text {-value }\end{array}$ & Product ions in MS/MS \\
\hline 761.7 & $\mathrm{~d} 16: 0 / 22: 0$ & $\mathrm{C}_{43} \mathrm{H}_{89} \mathrm{~N}_{2} \mathrm{O}_{6} \mathrm{P}$ & 15.0 & $184,560,578,340,364,238,761.7$ \\
775.7 & $\mathrm{~d} 16: 0 / 23: 0$ & $\mathrm{C}_{44} \mathrm{H}_{93} \mathrm{~N}_{2} \mathrm{O}_{6} \mathrm{P}$ & 12.9 & $184,592,574,354,238,775.6$ \\
789.7 & $\mathrm{~d} 18: 0 / 22: 0$ & $\mathrm{C}_{45} \mathrm{H}_{87} \mathrm{~N}_{2} \mathrm{O}_{6} \mathrm{P}$ & 16.0 & $184,606,588,340,266,789.7$ \\
803.7 & $\mathrm{~d} 18: 0 / 23: 0$ & $\mathrm{C}_{46} \mathrm{H}_{95} \mathrm{~N}_{2} \mathrm{O}_{6} \mathrm{P}$ & 15.8 & $184,620,602,266,803.7$ \\
677.6 & $\mathrm{~d} 16: 0 / 16: 0$ & $\mathrm{C}_{37} \mathrm{H}_{77} \mathrm{~N}_{2} \mathrm{O}_{6} \mathrm{P}$ & 11.7 & $184,494,476,256,677.6$ \\
705.6 & $\mathrm{~d} 18: 0 / 16: 0$ & $\mathrm{C}_{39} \mathrm{H}_{81} \mathrm{~N}_{2} \mathrm{O}_{6} \mathrm{P}$ & 12.8 & $184,522,504,705.6$ \\
759.6 & $\mathrm{~d} 16: 0 / 20: 4$ & $\mathrm{C}_{43} \mathrm{H}_{87} \mathrm{~N}_{2} \mathrm{O}_{6} \mathrm{P}$ & 12.7 & $184,558,576,364,340,236,759.6$ \\
773.7 & $\mathrm{~d} 16: 1 / 23: 0$ & $\mathrm{C}_{44} \mathrm{H}_{89} \mathrm{~N}_{2} \mathrm{O}_{6} \mathrm{P}$ & 13.1 & $184,590,572,378,236,773.7$ \\
787.7 & $\mathrm{~d} 18: 1 / 22: 0$ & $\mathrm{C}_{45} \mathrm{H}_{91} \mathrm{~N}_{2} \mathrm{O}_{6} \mathrm{P}$ & 15.5 & $184,604,586,364,340,264,787.6$ \\
799.7 & $\mathrm{~d} 18: 1 / 23: 1$ & $\mathrm{C}_{46} \mathrm{H}_{91} \mathrm{~N}_{2} \mathrm{O}_{6} \mathrm{P}$ & 13.7 & $184,616,598,262,799.7$ \\
801.7 & $\mathrm{~d} 18: 1 / 23: 0$ & $\mathrm{C}_{46} \mathrm{H}_{93} \mathrm{~N}_{2} \mathrm{O}_{6} \mathrm{P}$ & 16.1 & $184,618,600,378,354,264,801.7$ \\
813.8 & $\mathrm{~d} 18: 1 / 24: 1$ & $\mathrm{C}_{47} \mathrm{H}_{93} \mathrm{~N}_{2} \mathrm{O}_{6} \mathrm{P}$ & 15.7 & $184,630,612,264,813.8$ \\
815.8 & $\mathrm{~d} 18: 1 / 24: 0$ & $\mathrm{C}_{47} \mathrm{H}_{95} \mathrm{~N}_{2} \mathrm{O}_{6} \mathrm{P}$ & 16.6 & $184,632,614,392,368,264,815.8$ \\
675.6 & $\mathrm{~d} 16: 1 / 16: 0$ & $\mathrm{C}_{37} \mathrm{H}_{75} \mathrm{~N}_{2} \mathrm{O}_{6} \mathrm{P}$ & 11.2 & $184,474,280,236,675.6$ \\
703.6 & $\mathrm{~d} 18: 1 / 16: 0$ & $\mathrm{C}_{39} \mathrm{H}_{79} \mathrm{~N}_{2} \mathrm{O}_{6} \mathrm{P}$ & 12.3 & $184,520,502,280,264,703.6$ \\
731.6 & $\mathrm{~d} 18: 1 / 18: 0$ & $\mathrm{C}_{41} \mathrm{H}_{83} \mathrm{~N}_{2} \mathrm{O}_{6} \mathrm{P}$ & 13.4 & $184,548,530,284,731.6$ \\
\hline
\end{tabular}

${ }^{1} \mathrm{~m} / z=$ mass:charge ratio

${ }^{2}$ Values were accessed from the LIPID MAPS database (http://www.lipidmaps.org/data/structure) on Mar. 1, 2017. 
(A)
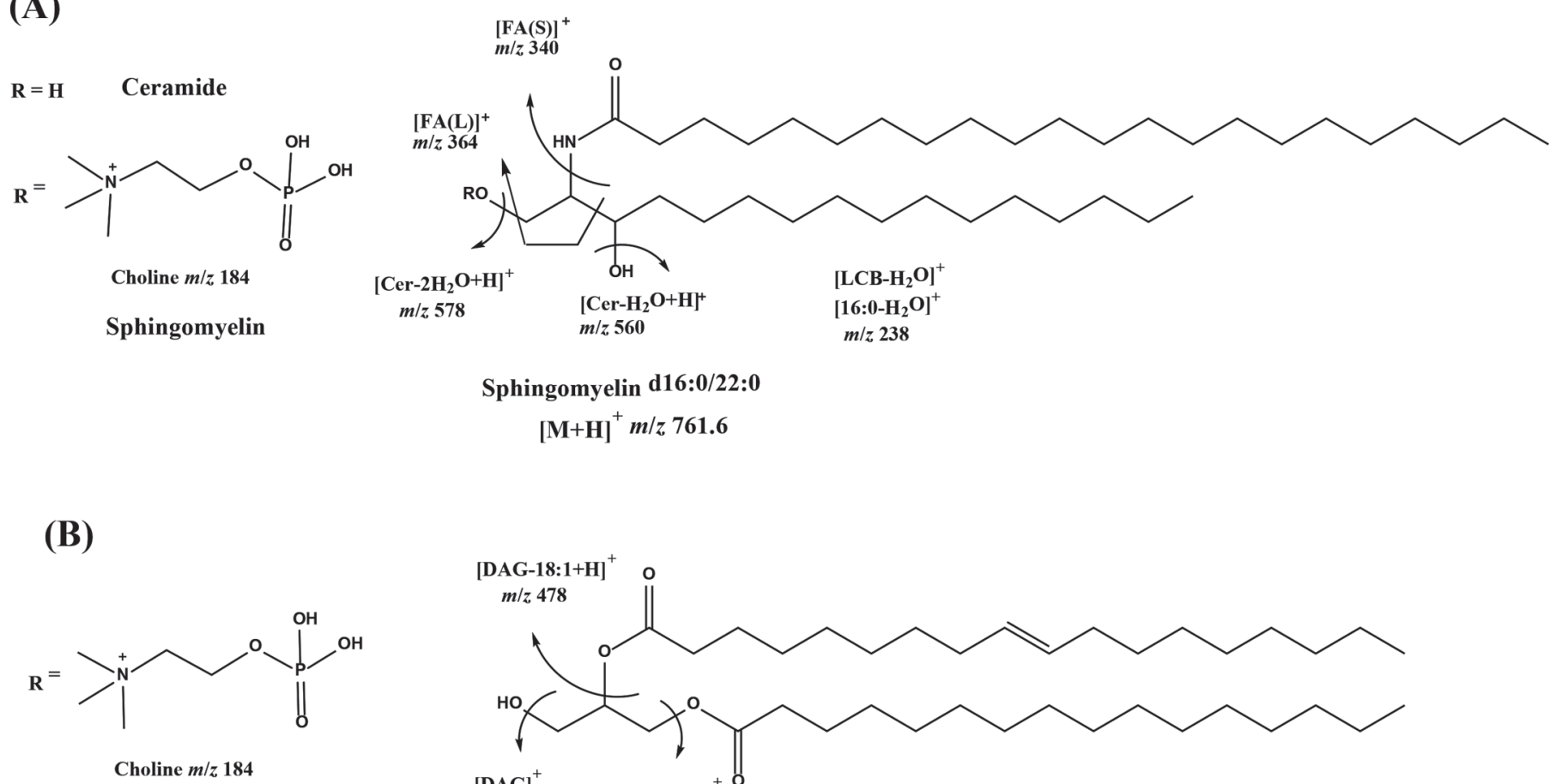

Phosphatidylcholine

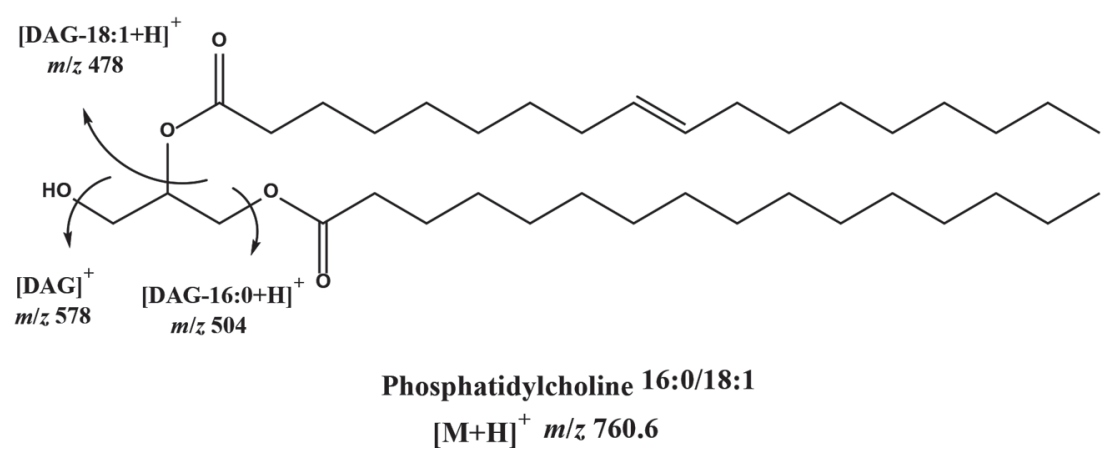

Figure 2. Schematic representation of structure and mass fragments of sphingomyelin and phosphatidylcholine. $m / z=$ mass:charge ratio. $[\mathrm{FA}(\mathrm{L})]+=$ protonated long chain fatty acid fragment; $[\mathrm{FA}(\mathrm{S})]+=$ protonated short chain fatty acid fragment; Cer $=$ ceramide; LCB $=$ long chain base; DAG = diacylglycerol.

with the presence of $\mathrm{m} / z 578$ and 560 corresponded to $\left[\text { Ceramide- } \mathrm{H}_{2} \mathrm{O}+\mathrm{H}\right]^{+}$and $\left[\text {Ceramide }-2 \mathrm{H}_{2} \mathrm{O}+\mathrm{H}\right]^{+}$, respectively. The product ions at $m / z 364$ and 340 corresponded to $[\mathrm{FA}(\mathrm{L})]^{+}$and $[\mathrm{FA}(\mathrm{S})]^{+}$fragments, confirming the presence of 22:0 FA chain of SM. The LCB of chain length d16:0 was further confirmed by $m / z 238$ indicating $\left[\mathrm{LCB}-\mathrm{H}_{2} \mathrm{O}\right]^{+}$fragment. The fragmentation is schematically presented in Figure 2. The composition of the SM was confirmed by comparing the masses of the molecular ion with mass fragments corresponding to specific chain lengths of long-chain bases and FA chains, as reported in literature (Hsu and Turk, 2000; Fong et al., 2007; Donato et al., 2011). The results were in agreement with previous literature suggesting that SM in bovine milk exist with most common bases of d16:0, d18:0, and d18:1 and with predominantly saturated chain lengths of C16:0, C22:0, and C23:0 (Fong et al., 2007).

The composition of other major classes of PC in whole and skim raw milk was also determined by analyzing the neutral losses of product ions in MS/ MS. Analysis of parent $m / z$ and product ions $m / z$ provided information to confirm 12 lipophilic PC (log $P=11.3-13.4)$ and 4 lyso-PC $(\log P=6.0-6.8)$ as shown in Table 3. The identification of PC and lyso$\mathrm{PC}$ was done using the dominant product ion at $\mathrm{m} / \mathrm{z}$ 184, a marker for the presence of phosphocholine polar group along with neutral losses of $m / z$ corresponding to specific fatty acyl chain lengths as shown in Figure 2. Diacylglycerol is the remaining component of $\mathrm{PC}$ with the loss of the phosphocholine head group. The protonated ion at $m / z 760.6$ was identified as PC consisting of fatty acyl chains 16:0/18:1. The major product ion at $\mathrm{m} / z 184$ confirmed the presence of the polar phosphocholine group along with the product ions at $m / z 478$ corresponding to $[\mathrm{M}+\mathrm{H}-18: 1]^{+}$, indicating the presence of C16:0 fatty acyl chain length with loss of $m / z 282$ (C18:1). Similarly, the product ions at $m / z$ 504 corresponding to $[\mathrm{M}+\mathrm{H}-16: 0]^{+}$with the loss of $m / z$ 256 (C16:0) indicated the presence of C18:0 fatty acyl chain. The $m / z$ values were compared with the previously reported fatty acyl chains, and C16:0 FA was the most commonly found chain length in PC (Zhao et al., 2011; Artegoitia et al., 2014). 


\section{Quantification of SM and PC in Bovine Milk}

The identified $16 \mathrm{SM}$ and $12 \mathrm{PC}$ were quantified $(\mu \mathrm{g} / 100 \mathrm{~mL})$ in whole raw milk and skim raw milk as shown in Figures 3 and 4 for early, mid, and late lactation. The concentration of SM in whole raw milk (Figure 3a) showed strong positive correlation with their respective concentrations in skim raw milk for early $(\mathrm{r}=0.92)$, mid $(\mathrm{r}=0.92)$, and late $(\mathrm{r}=0.92)$ lactation (Figure 3b). Overall, the maximum concentration of SM in whole raw milk was found in cows in late lactation, with candidates d18:1/23:0, d18:1/16:0, and d18:1/22:0 being present in the highest concentrations $(2,045.2 \pm 52.60 \mu \mathrm{g} / 100 \mathrm{~mL}, 1,893.2 \pm 48.9 \mu \mathrm{g} / 100$ $\mathrm{mL}$, and $1,578.9 \pm 52.9 \mu \mathrm{g} / 100 \mathrm{~mL}$, respectively), followed by d16:1/23:0 and d18:1/24:0. A previous study reported similar SM-that is, d18:1/16:0, d16:1/23:0, and $\mathrm{d} 18: 1 / 23: 0$ being the dominating candidates present in the MFGM (Fong et al., 2007). The majority of the SM in whole milk and MFGM were reported with high content of long-chain FA with chain lengths greater than C20, which is consistent with the current study (Sánchez-Juanes et al., 2009). The analysis of skim raw milk showed a maximum concentration of SM d18:1/23:0 and d18:1/22:0 found in late lactation (i.e., $670.7 \pm 15.1 \mu \mathrm{g} / 100 \mathrm{~mL}$ and $568.6 \pm 15.9 \mu \mathrm{g} / 100$ $\mathrm{mL}$, which accounted for 33 and $36 \%$ of the total SM concentration in whole raw milk, respectively). Other dominating SM included d18:1/24:0, d16:1/23:0, and $\mathrm{d} 16: 1 / 22: 0$, with their maximum concentration present in the milk from cows in late lactation, with 29 to $50 \%$ of their total content in whole raw milk found in skim raw milk.
The LC-MS/MS analysis of whole raw milk obtained from cows in early, mid, and late lactation showed the presence of PC 16:0/16:0, 16:0/18:1, 16:0/18:2, and 18:0/18:2, with maximum concentrations present in late lactation ranging from $1,922.0 \pm 86.3 \mu \mathrm{g} / 100 \mathrm{~mL}$ to $1,000.2 \pm 30.4 \mu \mathrm{g} / 100 \mathrm{~mL}$ (Figure $4 \mathrm{a}$ ). The concentration of $\mathrm{PC}$ in whole raw milk also showed a strong positive correlation with their respective concentrations in skim raw milk for early $(\mathrm{r}=0.93)$, mid $(\mathrm{r}=0.93)$, and late $(\mathrm{r}=0.90)$ lactation (Figure $4 \mathrm{~b})$. Analysis of the skim raw milk showed that PC candidates 16:0/18:1, 18:0/18:2, 16:0/16:0 were highly concentrated in late lactation, with 30,35 , and $16 \%$ of the PC initially present in whole raw milk appearing in skim raw milk, respectively. Although lysophosphatidylcholine (LPC) were present in low concentrations, $27 \%$ of the total LPC, C16:0, present in whole raw milk in late lactation was found in skim raw milk.

Graves et al. (2007) reported $38 \mathrm{mg} / \mathrm{L}$ of total SM in late-lactation milk, and higher values (up to $70 \mathrm{mg} / \mathrm{L}$ ) were previously reported for total SM in bovine milk (Bitman and Wood, 1990). However, there are no previous reports on the quantification of individual SM in milk with changing lactation. In the current study, a maximum SM concentration of $128 \mathrm{mg} / \mathrm{L}$ was calculated by combining the individual SM fractions from late-lactation whole milk. Similar to SM, increasing PC concentration in whole and skim milk was found as lactation progressed from early to late lactation (Figure 4a). This trend was in agreement with the results obtained in a previous study, where the concentration of PC increased from early to late lactation, with 16:0/18:1 being the dominating candidate (Artegoi-

Table 3. Identification of specific fatty acyl chains of phosphatidylcholine $\left(\mathrm{PC} ;[\mathrm{M}+\mathrm{H}]^{+}\right)$and lysophosphatidylcholine (LPC) in bovine milk

\begin{tabular}{lllrl}
\hline Ion $(m / z)^{1}$ & Fatty acid & $\begin{array}{l}\text { Molecular } \\
\text { formula }\end{array}$ & $\begin{array}{c}\text { Log } \\
P \text {-value }\end{array}$ & Product ions in MS/MS \\
\hline 760.6 & $16: 0 / 18: 1$ & $\mathrm{C}_{42} \mathrm{H}_{83} \mathrm{NO}_{8} \mathrm{P}$ & 12.6 & $184,478,496,504,522,577,760$ \\
758.6 & $16: 0 / 18: 2$ & $\mathrm{C}_{42} \mathrm{H}_{81} \mathrm{NO}_{8} \mathrm{P}$ & 12.4 & $184,478,496,502,520,575,758.6$ \\
756.6 & $16: 1 / 18: 2$ & $\mathrm{C}_{42} \mathrm{H}_{79} \mathrm{NO}_{8} \mathrm{P}$ & 12.2 & $184,476,494,502,520,573,756.6$ \\
788.7 & $18: 0 / 18: 1$ & $\mathrm{C}_{44} \mathrm{H}_{87} \mathrm{NO}_{8} \mathrm{P}$ & 13.4 & $184,504,506,522,524,788.6$ \\
786.6 & $18: 0 / 18: 2$ & $\mathrm{C}_{44} \mathrm{H}_{85} \mathrm{NO}_{8} \mathrm{P}$ & 13.2 & $184,502,506,520,524,786.6$ \\
784.6 & $18: 1 / 18: 2$ & $\mathrm{C}_{44} \mathrm{H}_{83} \mathrm{NO}_{8} \mathrm{P}$ & 12.9 & $184,502,504,520,522,784.6$ \\
782.6 & $16: 0 / 20: 4$ & $\mathrm{C}_{44} \mathrm{H}_{81} \mathrm{NO}_{8} \mathrm{P}$ & 12.7 & $184,478,496,526,782.6$ \\
780.6 & $18: 2 / 18: 3$ & $\mathrm{C}_{44} \mathrm{H}_{79} \mathrm{NO}_{8} \mathrm{P}$ & 12.3 & $184,500,502,518,520,780.6$ \\
706.5 & $16: 0 / 14: 0$ & $\mathrm{C}_{38} \mathrm{H}_{76} \mathrm{NO}_{8} \mathrm{P}$ & 11.3 & $184,478,496,450,706.5$ \\
734.6 & $16: 0 / 16: 0$ & $\mathrm{C}_{40} \mathrm{H}_{80} \mathrm{NO}_{8} \mathrm{P}$ & 12.1 & $184,478,496,734.6$ \\
732.6 & $18: 1 / 14: 0$ & $\mathrm{C}_{40} \mathrm{H}_{79} \mathrm{NO}_{8} \mathrm{P}$ & 11.8 & $184,4,466,504,734.6$ \\
730.6 & $18: 1 / 14: 1$ & $\mathrm{C}_{40} \mathrm{H}_{77} \mathrm{NO}_{8} \mathrm{P}$ & 11.6 & 184,478 \\
496.3 & LPC $16: 0$ & $\mathrm{C}_{24} \mathrm{H}_{51} \mathrm{NO}_{7} \mathrm{P}$ & 6.01 & 184,506 \\
524.4 & LPC $18: 0$ & $\mathrm{C}_{26} \mathrm{H}_{55} \mathrm{NO}_{7} \mathrm{P}$ & 6.79 & $184,504,522$ \\
522.4 & LPC $18: 1$ & $\mathrm{C}_{26} \mathrm{H}_{53} \mathrm{NO}_{7} \mathrm{P}$ & 6.55 & 184,502 \\
520.3 & LPC $18: 2$ & $\mathrm{C}_{26} \mathrm{H}_{51} \mathrm{NO}_{7} \mathrm{P}$ & 6.34 & $184,450,468,504,522,34$ \\
\hline
\end{tabular}

${ }^{1} \mathrm{~m} / z=$ mass:charge ratio.

${ }^{2}$ Values were accessed from the LIPID MAPS database (http://www.lipidmaps.org/data/structure) on Mar. $1,2017$. 


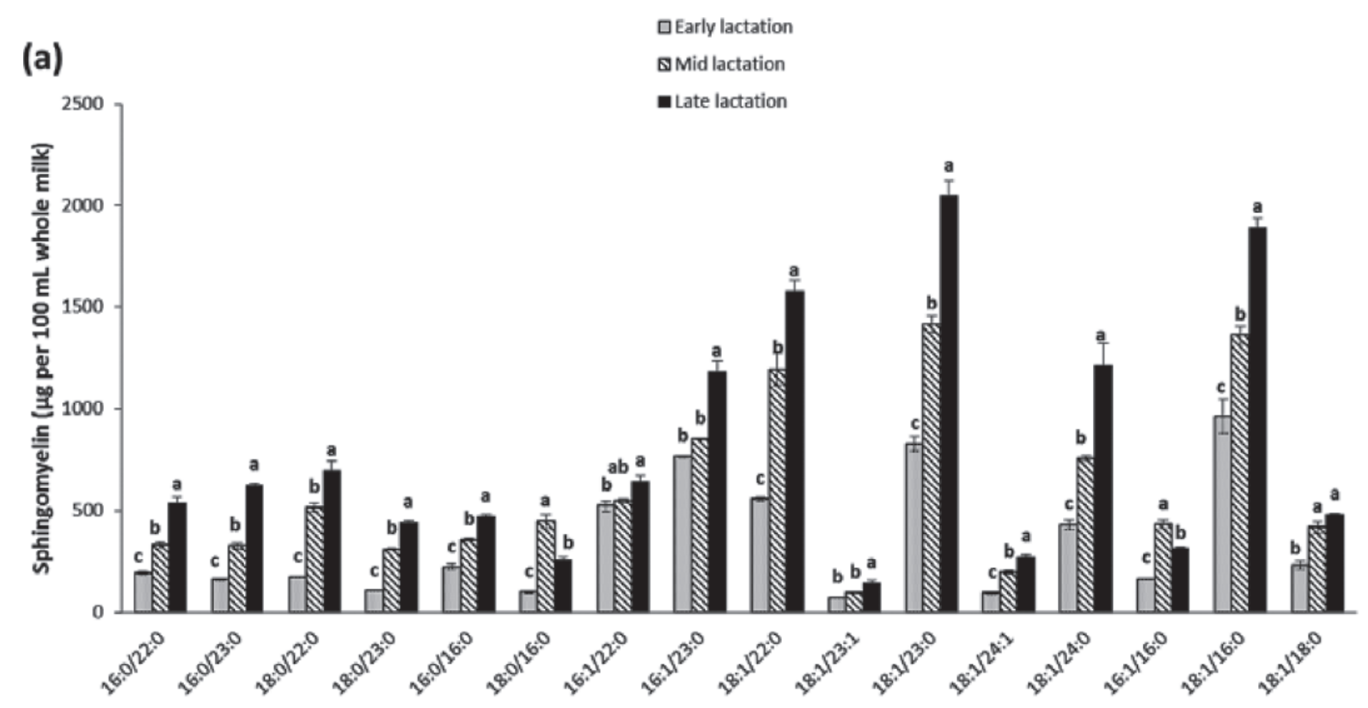

(b)

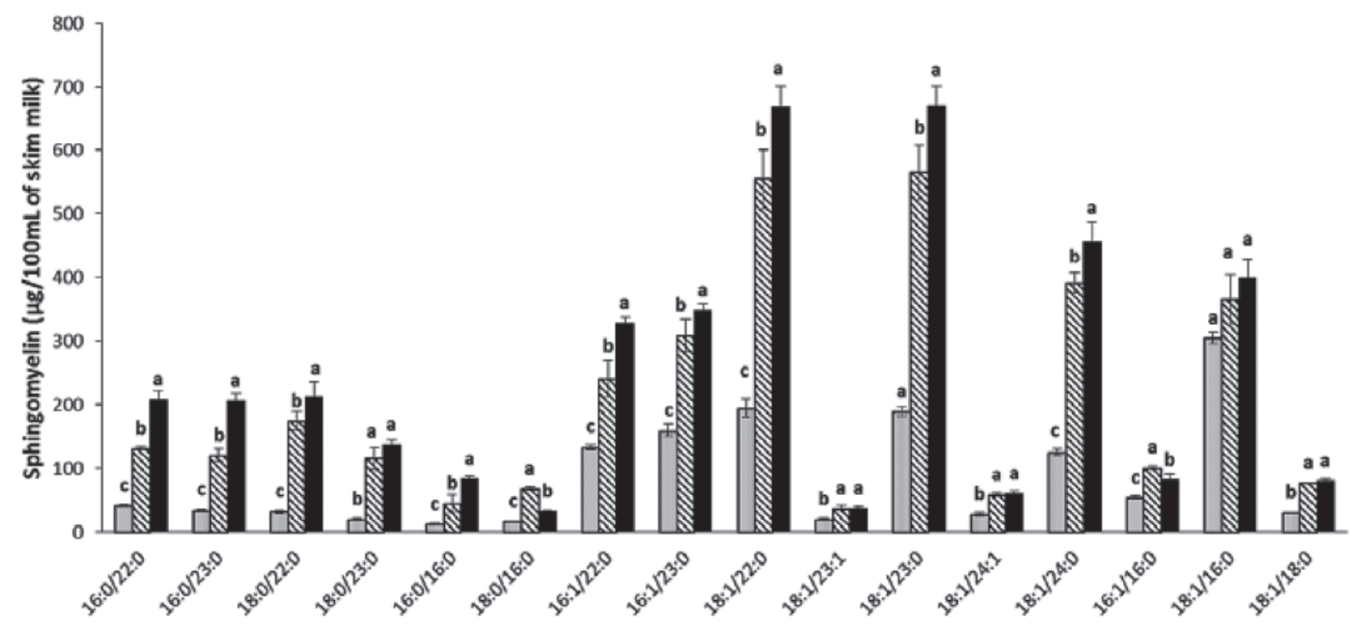

(c)

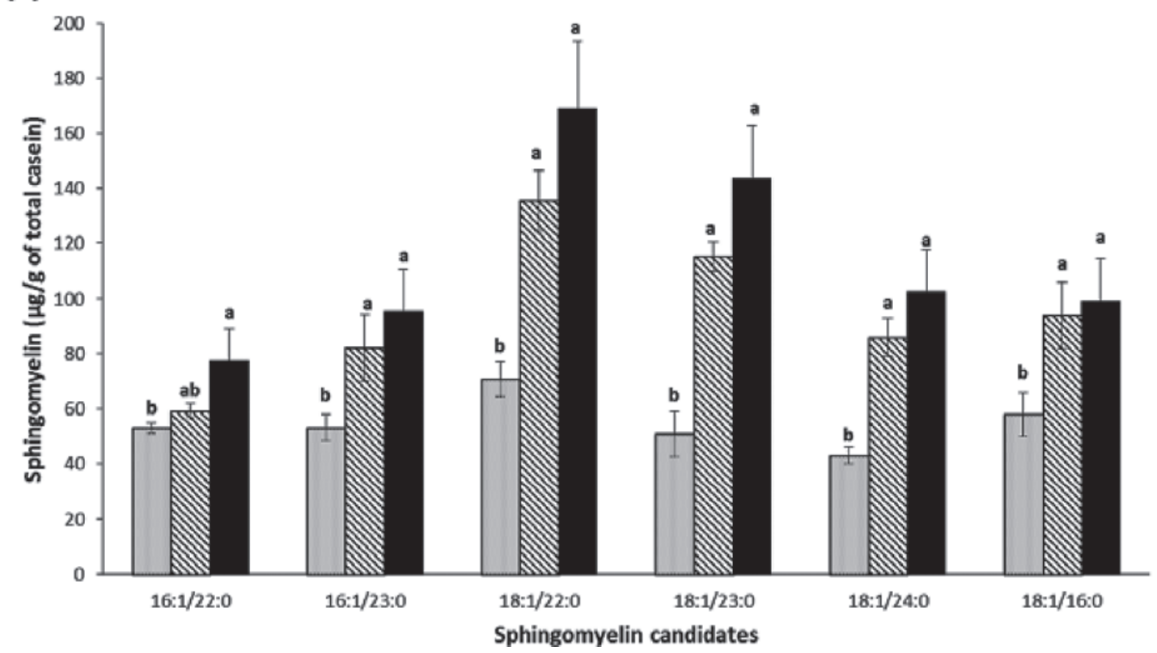

Figure 3. (a) Changes in concentration of sphingomyelins (SM; $\mu \mathrm{g} / 100 \mathrm{~mL}$ ) in whole raw milk as a function of lactation stages. (b) Changes in concentration of SM $(\mu \mathrm{g} / 100 \mathrm{~mL}$ ) in skim raw milk as a function of lactation stages. (c) Changes in concentration of SM ( $\mu \mathrm{g} / \mathrm{g}$ of casein protein) associated with casein proteins as a function of lactation stages. All values are mean $\pm \mathrm{SE} ; \mathrm{n}=3$. Means with different letters (a-c) represent differences between SM found in early, mid, and late lactation. 


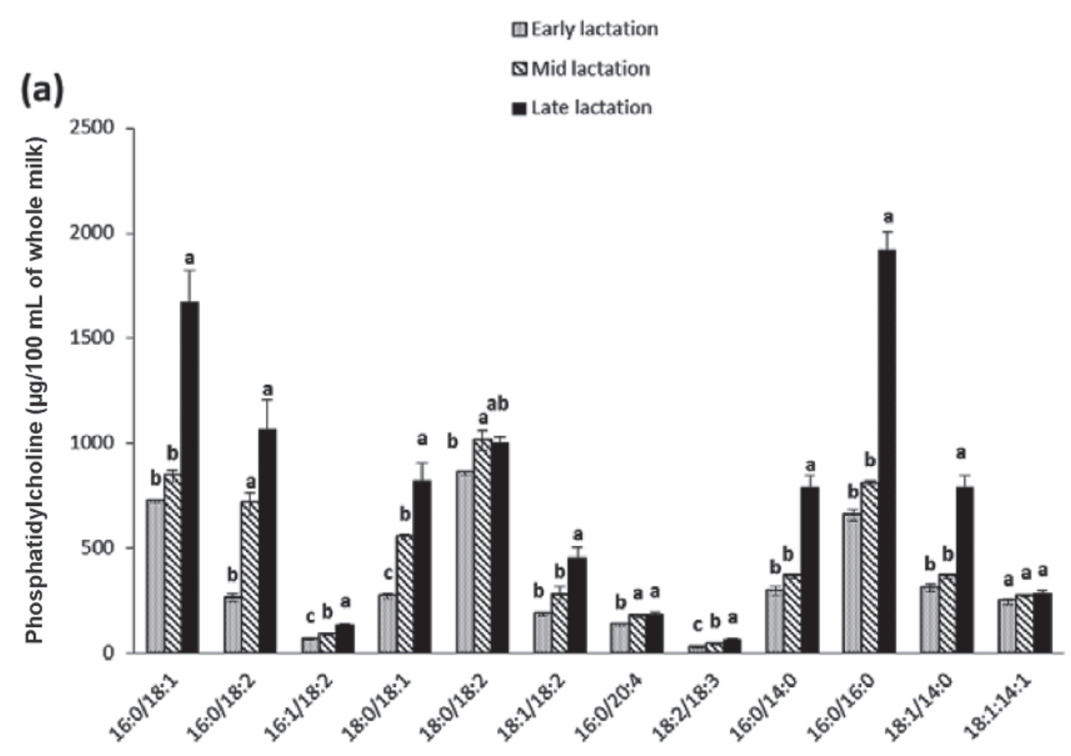

(b)

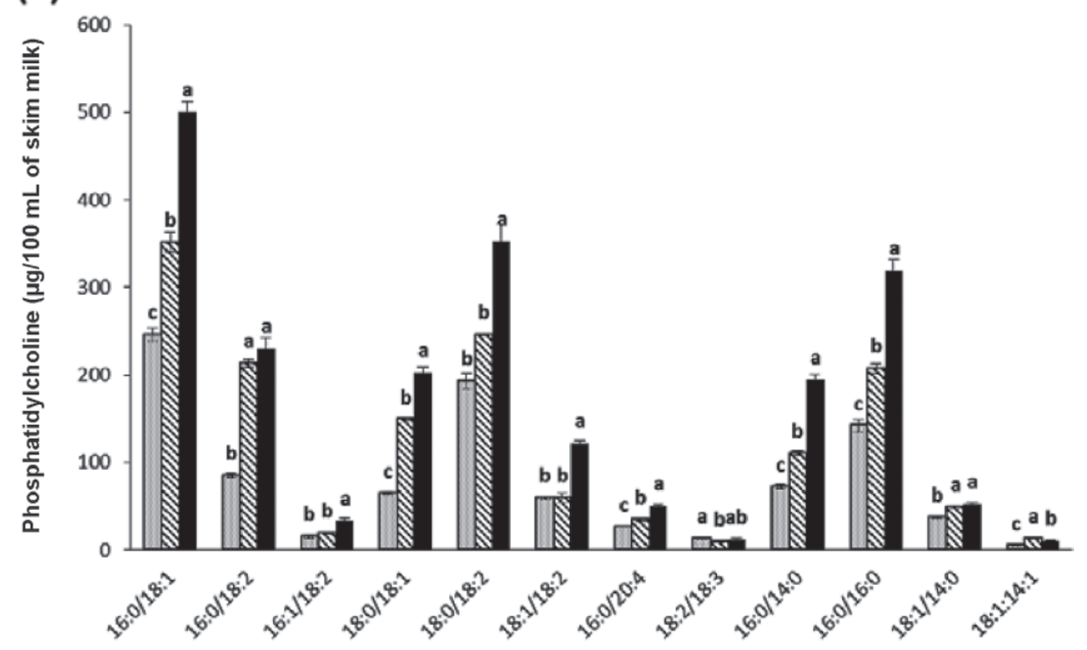

(c)

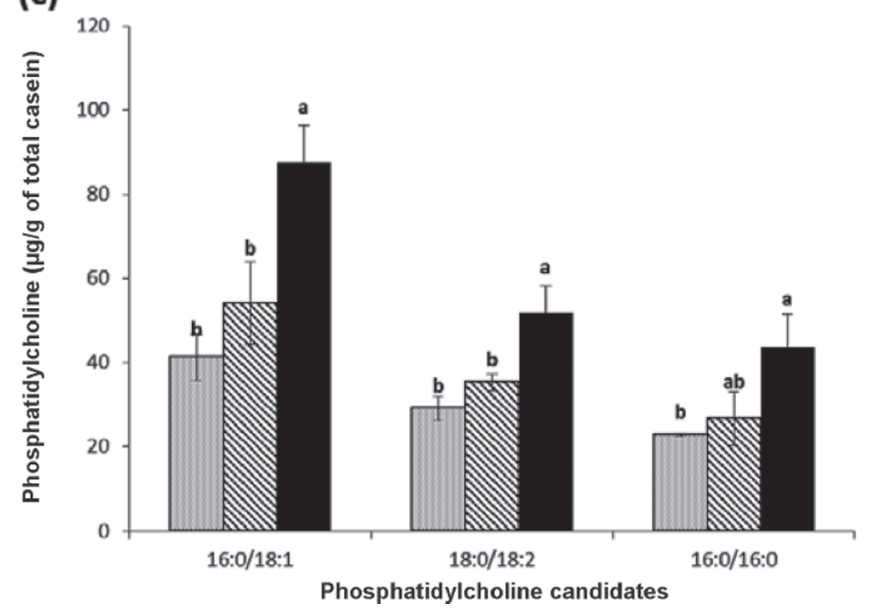

Figure 4. (a) Changes in concentration of phosphatidylcholine (PC; $\mu \mathrm{g} / 100 \mathrm{~mL}$ ) in whole raw milk as a function of lactation stages. (b) Changes in concentration of PC $(\mu \mathrm{g} / 100 \mathrm{~mL}$ ) in skim raw milk as a function of lactation stages. (c) Changes in concentration of PC ( $\mu \mathrm{g} / \mathrm{g}$ of casein protein) associated with casein proteins as a function of lactation stages. All values are mean \pm SE; $\mathrm{n}=3$. Means with different letters $(\mathrm{a}-\mathrm{c})$ represent differences between PC found in early, mid, and late lactation. 
tia et al., 2014). The total PC content calculated by combining the individual PC concentrations present in late-lactation whole milk was $96 \mathrm{mg} / \mathrm{L}$, which was higher compared with the values of 26 to $54 \mathrm{mg} / \mathrm{L}$ previously reported for whole milk (Christie et al., 1987; Sánchez-Juanes et al., 2009) and close to the $90 \mathrm{mg} / \mathrm{L}$ of total PC reported by Bitman and Wood (1990). The variability in reported $\mathrm{PC}$ content could be partially explained by the differences in extraction protocols of phospholipids, analytical method of detection, and animal physiology (lactation stage and diet; Bitman and Wood, 1990; Lopez et al., 2008). The concentration $(\mu \mathrm{g} / 100 \mathrm{~mL}$ of milk) of individual SM and PC are shown in Supplemental Tables S1 and S2 (https://doi .org/10.3168/jds.2017-14137).

The fat content of bovine milk decreases from early to late lactation with a concomitant increase in total phospholipid content (Zou et al., 2015). Graves et al. (2007) reported an increase in total SM content in bovine milk $(>200$ DIM) and a reduction in the fat content and fat globule size as the lactation stage progressed. Because the fat globule size decreases with the progression of lactation stage, the surface-to-volume ratio increases, hence increasing the amount of SM and MFGM needed to cover the surface of smaller fat globules (Lopez et al., 2011). Lopez et al. (2011) hypothesized that changes in the local curvature of the MFGM during the release of smaller milk fat globules in the mammary epithelial cells would lead to the loss of some membrane materials (e.g., PC and SM) into the serum of late-lactation milk.

In the current study, skim milk was found to be a significant source of choline containing PL, with approximately 21 to $50 \%$ of the most abundant SM candidates and approximately 16 to $35 \%$ of the most abundant PC candidates initially present in whole milk appearing in skim milk in late lactation. This is consistent with previous reports that $\mathrm{SM}$ and $\mathrm{PC}$ appeared in skim milk even after removal of the milk fat (Christie et al., 1987; Zeisel et al., 2003). The MFGM is reported to undergo various compositional and structural changes after secretion form the mammary cell, leading to shedding of membrane material into the serum phase (Rombaut et al., 2006). Because SM and PC are reported to be concentrated on the outer layer of the MFGM membrane, these PL are likely to be released into the milk matrix in case of destabilization of the MFGM membrane (Zheng et al., 2014). Although the centrifugation speed used to generate skim milk in the current study was considerably low $(\sim 6,000 \times g)$, this mechanical action could potentially lead to the release of MFGM membrane material such as PC and SM into the skim milk.

The concentration of total SM in skim raw milk was $1.51 \pm 0.01 \mathrm{mg} / 100 \mathrm{~mL}, 3.36 \pm 0.02 \mathrm{mg} / 100 \mathrm{~mL}$, and
$4.01 \pm 0.04 \mathrm{mg} / 100 \mathrm{~mL}$ for early, mid, and late lactation, respectively, corresponding to approximately $27 \%$ (early), $35 \%$ (mid), and $31 \%$ (late) of the total SM initially found in whole raw milk. The total content of $\mathrm{PC}$ in skim raw milk was $0.96 \pm 0.01 \mathrm{mg} / 100 \mathrm{~mL}, 1.46$ $\pm 0.01 \mathrm{mg} / 100 \mathrm{~mL}$, and $2.08 \pm 0.04 \mathrm{mg} / 100 \mathrm{~mL}$ for early, mid, and late lactation, respectively, corresponding to approximately $24 \%$ (early), $26 \%$ (mid), and $23 \%$ (late) of the total PC initially found in whole raw milk.

The percentage distribution of each SM and PC candidate in skim milk compared with whole milk is shown in Supplemental Figures S1a and S2a (https://doi.org/ 10.3168/jds.2017-14137). Although no significant differences were observed in the relative percentage distribution of each candidate versus total SM or PC with the progression of lactation stage, statistical analysis showed significant interaction between the phospholipid relative content and lactation stage (Supplemental Tables S3a and S4a; https://doi.org/10.3168/jds.2017 -14137).

\section{Quantification of SM and PC Associated with Casein Micelles}

Figures $3 \mathrm{c}$ and $4 \mathrm{c}$ were obtained by combining the amount of specific SM and PC associated with the total amount of casein proteins $(\mu \mathrm{g} / \mathrm{g})$ isolated from $5 \mathrm{~mL}$ of skim raw milk using SEC for each lactation. The most abundant SM associated with caseins were found in late lactation, consisting of 35 to $46 \%$ of the total SM found in skim raw milk (Figure 3c). There was a significant increase in the amount of SM associated with the casein micelle fraction $(\mu \mathrm{g} / \mathrm{g})$ from early to mid lactation $(P<0.05)$, whereas their concentration did not differ significantly from mid to late lactation. A strong positive correlation was found between the concentration of $\mathrm{SM}$ in whole raw milk and the concentration associated with the casein micelle fraction for early $(\mathrm{r}=0.89)$, mid $(\mathrm{r}=0.92)$, and late $(\mathrm{r}=0.91)$ lactations.

The concentration of PC in whole raw milk and in the casein micelle fraction also showed strong positive correlation for early $(\mathrm{r}=0.91)$, mid $(\mathrm{r}=0.89)$, and late $(\mathrm{r}=0.87)$ lactation. The most abundant $\mathrm{PC}$ candidates associated with the casein micelle fraction accounted for 22 to $29 \%$ of total PC found in skim raw milk (Figure 4). Overall, there was an increase in the concentration of PC associated with casein micelles going from mid to late lactation for the 3 dominating PC candidates $(P<$ $0.05)$, and no significant differences between early and mid lactation were found (Figure 4c).

Sphingomyelins and PC are highly significant in early neurological development, and there is a current emphasis on the matching of infant formula composition with that of human milk to provide complete 
nutrition. Furthermore, approximately $17 \%$ of the total choline consumed by newborns is obtained from SM and PC (Sala-Vila et al., 2005). A recent study reported improved neurological development of lowbirth-weight infants when using formula supplemented with 20\% SM (of the total phospholipids) from milk phospholipids compared with 13\% SM (of the total phospholipids) from egg phospholipids (Tanaka et al., 2013). The SM are also known to play an important role in the gut maturation of suckling neonates, and the average daily intake of SM by infants is reported to be approximately $62 \mathrm{mg} / \mathrm{d}$ when consuming an average of $800 \mathrm{~mL}$ of human milk/d (Garcia et al., 2012). Human milk contains a total phospholipid content ranging from 15 to $81 \mathrm{mg} / 100 \mathrm{~mL}$, of which choline-containing phospholipids SM constitutes the highest percentage $(28-35 \%)$ of the total phospholipid content (8.0-16.5 $\mathrm{mg} / 100 \mathrm{~mL}$ of milk) followed by PC $(3.6-8.1 \mathrm{mg} / 100$ $\mathrm{mL}$; Claumarchirant et al., 2016). In comparison, the total phospholipid content in whole bovine milk ranges from 10 to $40 \mathrm{mg} / 100 \mathrm{~mL}$, of which choline-containing phospholipid $\mathrm{PC}$ is the dominating candidate, ranging from 8.0 to $45.5 \%$ of the total PL content, followed by SM (4.1-29.2\%; Christie et al., 1987; Bitman and Wood, 1990; Contarini and Povolo, 2013). The concentration of the major choline phospholipids SM and $\mathrm{PC}$ in various infant formulas ranged from 6.0 to 13.7 $\mathrm{mg} / 100 \mathrm{~mL}$ and 4.6 to $8.7 \mathrm{mg} / 100 \mathrm{~mL}$, respectively (Claumarchirant et al., 2016). Various studies reported adding MFGM to enhance the concentration of SM and $\mathrm{PC}$ in infant formula to match the composition found in human milk (Claumarchirant et al., 2016; Timby et al., 2017).

In the current study, a maximum of approximately $16.0 \mathrm{mg}$ of $\mathrm{SM}$ and $5.0 \mathrm{mg}$ of $\mathrm{PC}$ were obtained from $17 \mathrm{~g}$ of casein micelles isolated from $1 \mathrm{~L}$ of raw skim milk in late lactation. On average, the casein proteins account for approximately $26.4 \mathrm{~g}$ of protein/L of milk (assuming $80 \%$ casein and $3.3 \%$ protein content). The difference in amount of casein proteins in the current study is attributed to the large initial peak outside the resolution range for the SEC column (Figure 1, fraction $1 \mathrm{~B}_{3}$ ). Assuming that larger casein micelles carry at least similar SM and PC content, it is expected that the fortification of milk with casein micelle isolates from 1 $\mathrm{L}$ of late-lactation milk will contribute approximately $25 \mathrm{mg}$ of SM and $8 \mathrm{mg}$ of PC. The micellar casein proteins from late-lactation bovine milk, added to the infant formula mainly as a source of protein, can also fortify the concentration of lipid-soluble SM and PC.

Further analysis of the 5 fractions of varying casein micelle size obtained from SEC showed differences in the partitioning of SM and PC into casein micelles with respect to their size. The SM d18:1/22:0, d18:1/
23:0, d18:1/16:0, d18:1/24:0, d16:1/23:0, and d16:1/22: 0 were found to be the most abundant candidates (concentration $>100 \mu \mathrm{g} / \mathrm{g}$ of casein protein). The maximum concentration of SM was associated with the largest casein micelles (diameter $=149 \mathrm{~nm}$ ) in late lactation, with average content ranging from $152.4 \pm 16.4 \mu \mathrm{g} / \mathrm{g}$ of casein for d16:1/22:0 to $343.1 \pm 17.4 \mu \mathrm{g} / \mathrm{g}$ of casein for d18:1/22:0 (Figure 5). There was a significant reduction in SM concentration in casein micelles as the casein micelles size decreased $(P<0.05$; Figure 5$)$ in late and mid lactation. However, differences in SM concentration due to casein micelle diameter were not significant in early lactation. Differences in the concentration of the less abundant SM candidates (below $100 \mu \mathrm{g} / \mathrm{g}$ of casein protein) with respect to casein micelle size and lactation are shown in Supplemental Figure S3 (https:/ /doi.org/10.3168/jds.2017-14137).

Similar to SM, the most abundant PC 16:0/18:1, 18:0/18:2, and 16:0/16:0 were found to be associated with the largest casein micelles in late lactation, with $180.2 \pm 20.1,98.4 \pm 4.5$, and $98.3 \pm 12.4 \mu \mathrm{g}$ of $\mathrm{PC} / \mathrm{g}$ of casein protein, respectively (Figure 6). There was a significant reduction $(P<0.05)$ in the concentrations of PC as the casein micelle size decreased for early, mid, and late lactation. The changes in all PC concentrations with maximum concentration $<40 \mu \mathrm{g} / \mathrm{g}$ of casein protein are shown in Supplemental Figure S4 (https:/ /doi.org/10.3168/jds.2017-14137). Although LPC 16:0, 18:0, 18:0, and 18:2 were found in very small concentrations (i.e., $<10 \mu \mathrm{g} / \mathrm{g}$ ), their maximum concentration was also found in late lactation, except for 18:2, which was mainly found in mid lactation. Overall, a significant reduction in the concentration of associated SM and PC was found with decreasing casein micelle sizes, as shown in Figures 5 and 6 . The percentage distribution of each SM and PC candidate in casein micelles compared with raw skim milk and whole milk is represented in Supplemental Figures S1b-c and S2b-c (https://doi .org/10.3168/jds.2017-14137).

The relative casein protein composition of casein micelles is known to change with micellar size. Dalgleish et al. (1989) reported that the relative content of $\kappa$-casein increased from approximately $5.7 \%$ in larger casein micelles (diameter $=149 \mathrm{~nm}$ ) to approximately $8.7 \%$ in smaller casein micelles (diameter $=87 \mathrm{~nm}$ ), and the $\beta$-casein decreased from approximately $39 \%$ to $35 \%$ as casein micelle diameter decreased. The authors also reported that the decrease in $\kappa$-casein proportion was compensated by an increase in $\beta$-casein, with both $\alpha_{S}$-caseins being independent of micelle size. The claim was supported by observing a reduction in casein phosphate content with reduction in micellar size as 5 phosphoserine residues from every $\beta$-casein monomer were replaced by 1 phosphoserine residue from $\kappa$-casein. The 
hydrophobic domains in $\beta$-casein are also known to play an important role in interacting with hydrophobic probes via hydrophobic and electrostatic interactions (e.g., vitamin D and chemotherapeutic drugs; Sahu et al., 2008; Shapira et al., 2010a,b). Correlation analysis for SM 18:1/22:0 showed positive correlation with $\beta$-casein previously reported relative content $(\mathrm{r}=0.97)$ and negative correlation with $\kappa$-casein relative content $(\mathrm{r}=-0.97)$ for casein micelles of average diameter ranging from 149 to $87 \mathrm{~nm}$. Donnelly et al. (1984) reported similar changes in $\kappa$-casein proportions increasing from approximately $4.1 \%$ to $8.2 \%$ and $\beta$-casein proportions

(a)

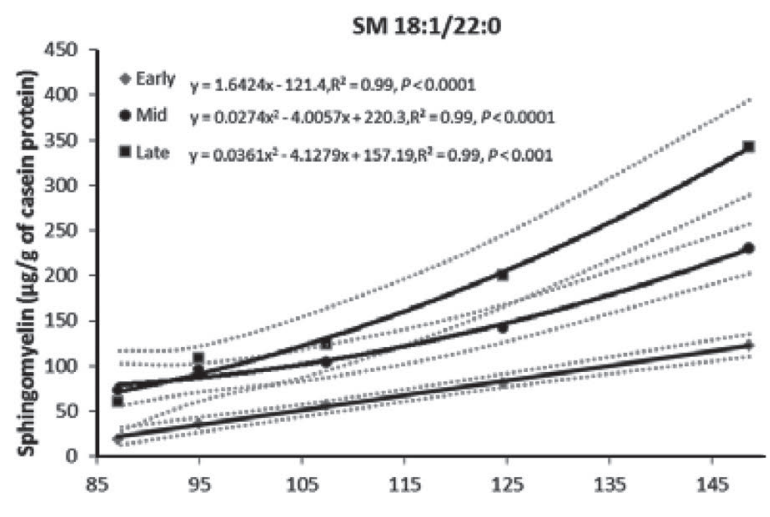

(c)

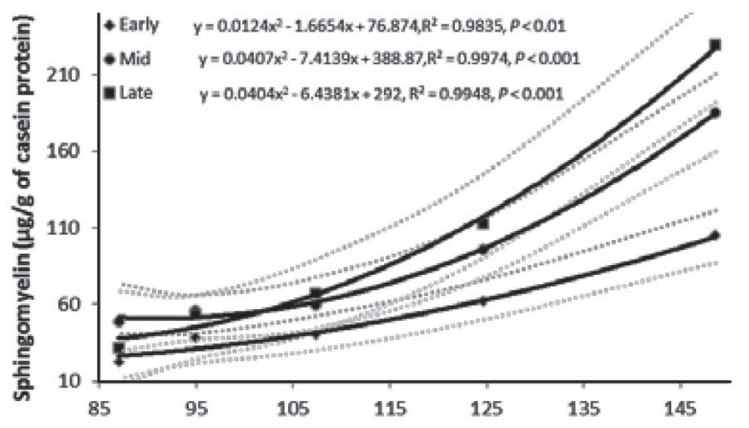

(e)

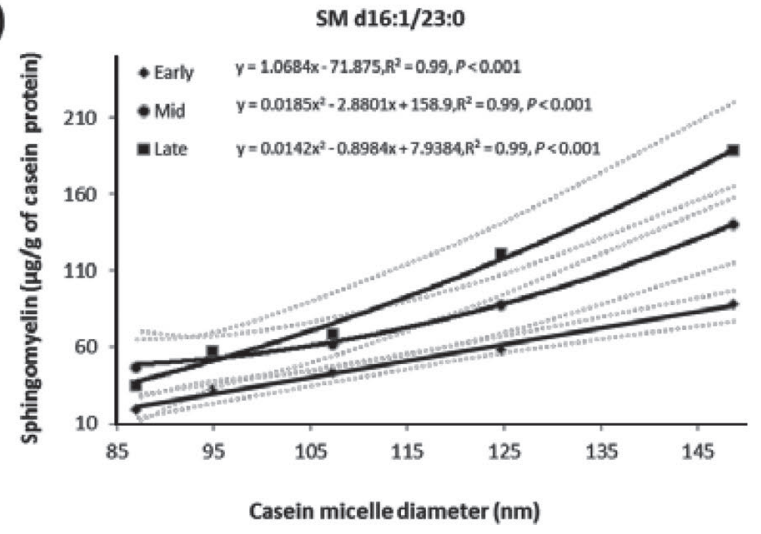

decreasing from $37 \%$ to $34 \%$ with decreasing casein micelle size from $154 \mathrm{~nm}$ to $82 \mathrm{~nm}$; the authors also reported changes in $\alpha_{S^{-}}$-casein content (50\% to $\left.46 \%\right)$ as the casein micelle size decreased.

The association of hydrophobic SM and PC can be attributed to the "sponge-like" structure of the casein micelles and its dynamic interaction with the surrounding environment. In recent years, it was proposed that the casein micelles possess a nonhomogeneous internal structure consisting of serum channels (Dalgleish, 2011; Trejo et al., 2011) that can contribute to providing access to hydrophobic domains in the internal structure (b)

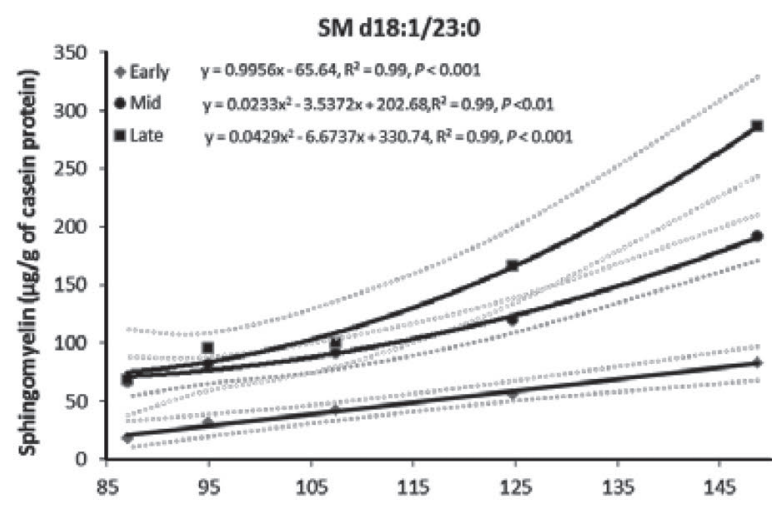

(d)

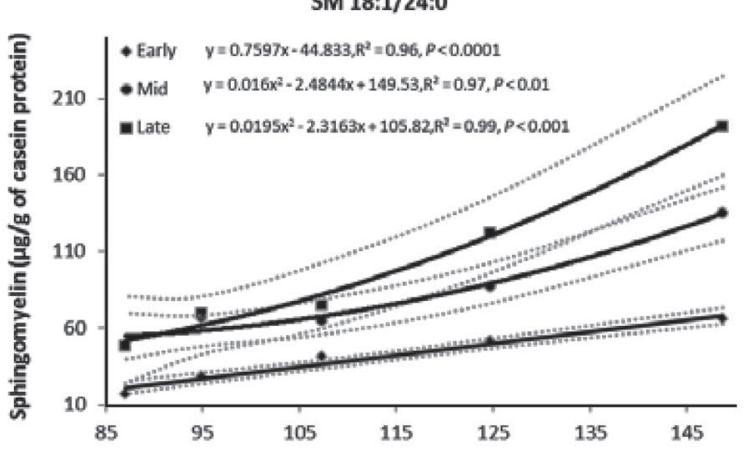

(f)

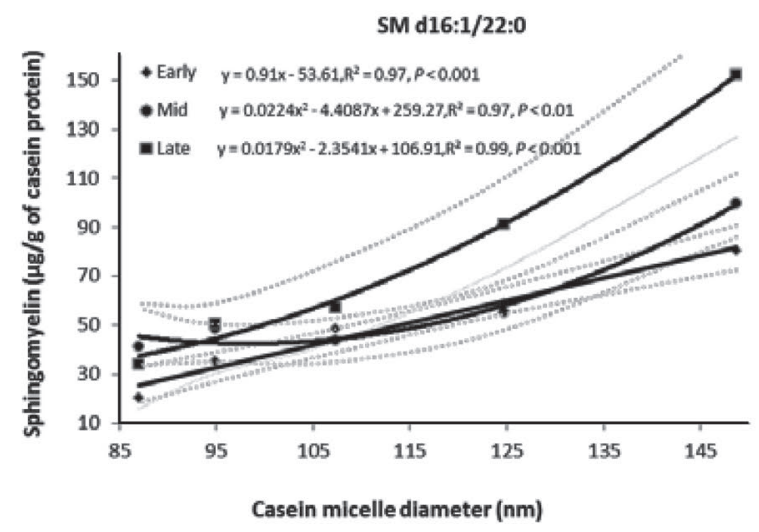

Figure 5. Relationship between sphingomyelin (SM) concentrations associated with casein protein ( $\mu \mathrm{g} / \mathrm{g}$ of casein protein) and casein micelle diameter. Dotted lines represent $95 \%$ confidence interval for SM regression curves for early, mid, and late lactation. 
(a)

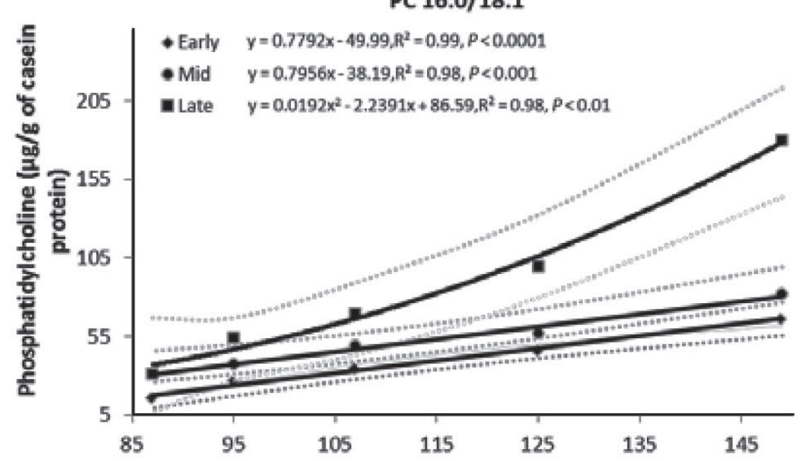

(c)

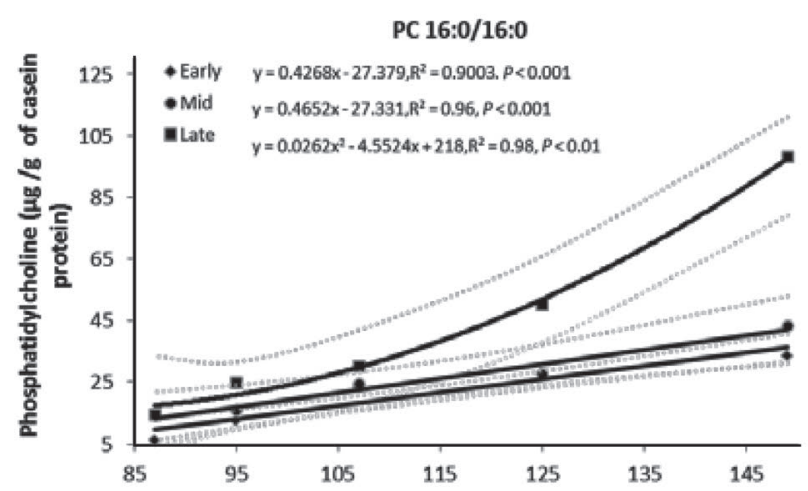

(e)

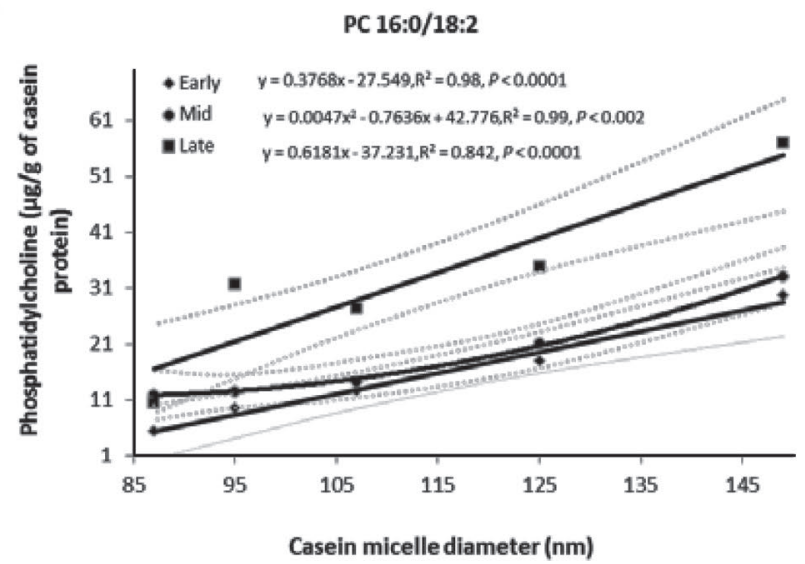

(b)

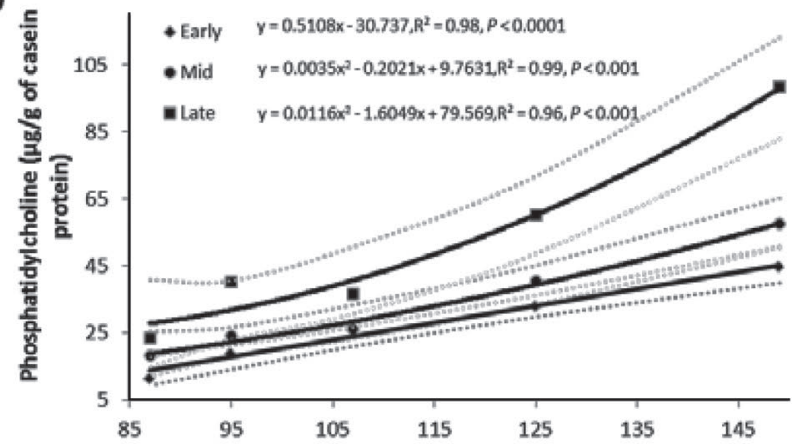

(d)

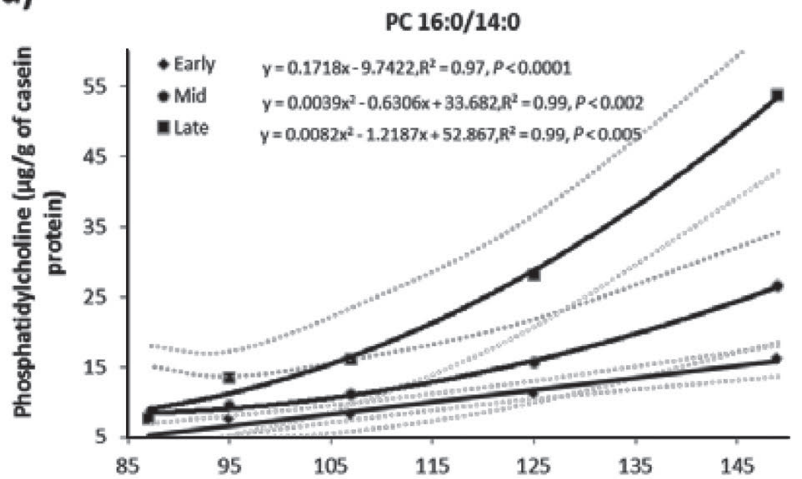

(f)

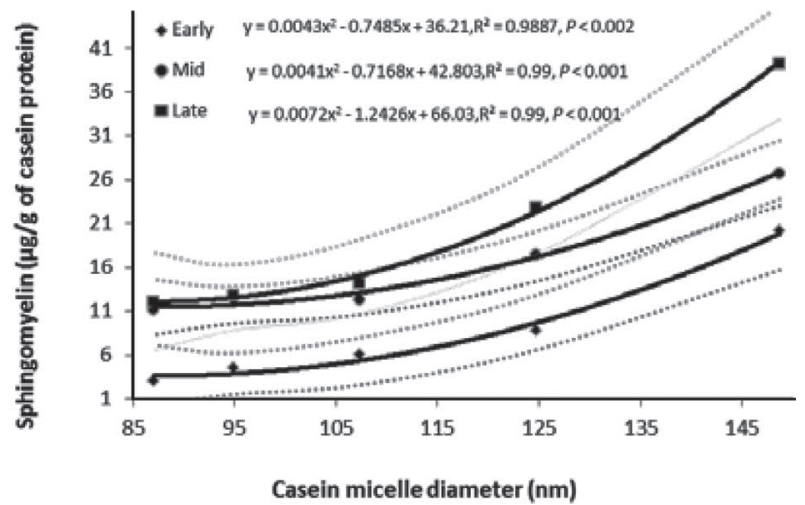

Figure 6. Relationship between phosphatidylcholine $(\mathrm{PC})$ and sphingomyelin $(\mathrm{SM})$ concentrations associated with casein proteins ( $\mu \mathrm{g} / \mathrm{g}$ of casein protein) and casein micelle diameter. Dotted lines represent $95 \%$ confidence interval for PC regression curves for early, mid, and late lactation.

of the casein micelle. For instance, $\beta$-casein contains hydrophobic domains, and Sahu et al. (2008) used fluorescent spectroscopy to confirm the interactions between these domains and hydrophobic probes. The observed reduction in the concentration of hydrophobic SM and PC associated with smaller caseins could be explained by the previously reported reduction in $\beta$-casein amounts in smaller casein micelles size. Over- all, it is hypothesized that the lipid-soluble SM and PC appearing in skim milk would tend to partition into the casein micelles via hydrophobic interactions with the domains present in the $\beta$-casein located primarily in the interior of the micelles. The increase in diameter of larger versus smaller casein micelles was 1.7 fold, corresponding to an approximately 5 -fold increase in volume (Figures 5 and 6). The concentration of associated SM 
and PC with casein micelles in late lactation followed an approximately linear relationship with the volume of the casein micelles (diameter ${ }^{3}$ ), supporting the hypothesis that the lipid-soluble PL preferably partitioned into the interior domains of the micelles. Whether the observed association between casein micelles and $\mathrm{SM}-\mathrm{PC}$ is innate to milk (i.e., naturally occurs in the mammary gland) or results from the shearing of the MFGM during centrifugation remains to be elucidated. If the latter is the case, a similar or larger association between casein micelles and SM-PC is to be expected in commercial skim milk. This is because the pumping and centrifugation systems in industrial setups are expected to create even larger damage to the fat globule membrane versus the separation conditions used in this experiment $(6,414 \times g$ for $20 \mathrm{~min})$.

Isolates of $\beta$-casein were reported to interact with phospholipids present in the MFGM in bovine milk via electrostatic and hydrophobic interactions (Gallier et al., 2012). Several studies were conducted to understand the interaction between $\beta$-casein and individual PC, including dipalmitoyl-PC (16:0/16:0) and dioleoylPC (18:1/18:1), when located in the air-water interface (Caro et al., 2007, 2009; Rodríguez Niño et al., 2009). The interactions between $\beta$-casein and individual PC were explained by a combination of hydrophobic interactions and $\mathrm{pH}$-dependent electrostatic interactions. At $\mathrm{pH} 6.8, \beta$-caseins possess negative net charge due to negatively charged phosphoserine residues, whereas the rest of the protein is highly hydrophobic. The choline head groups of PC are zwitterions, resulting in potential weak electrostatic interactions between charged groups present in $\beta$-caseins and PC. However, electrostatic interactions may play a minor role in explaining micellar $\beta$-casein-PC interaction because $\beta$-casein charge is mostly neutralized by calcium phosphate nanoclusters in the casein micelle. Furthermore, Bourasaa et al. (2014) studied the interactions of specific phospholipids with individual $\alpha$ - and $\beta$-casein isolates and concluded that the phospholipid-casein interactions were mainly hydrophobic in nature.

Although the association of whey proteins with phospholipids was not investigated in the current study, the SM and PC content not associated with the casein micelles was either suspended in the milk serum in free form or bound to the whey proteins ( $\beta-L G, \alpha-L A)$. $\beta$-Lactoglobulin is known to bind hydrophobic ligands, including vitamin A, palmitic acid, linolenic acid, and w-FA (Puyol et al., 1991; Zimet and Livney, 2009; Le Maux et al., 2014). $\beta$-Lactoglobulin is also known to interact with phospholipids via hydrophobic and electrostatic interactions (Martins et al., 2008; Mandalari et al., 2009). The focus of the current study was to investigate the association between polar hydrophobic $\mathrm{PC}$ and SM and native casein micelles. Although 35 to $46 \%$ of most abundant SM and 22 to $29 \%$ of most abundant PC present in skim raw milk were found associated with casein micelles in late lactation, the hypothesis is that the remaining amount of SM and PC is present either in the serum phase in free form or in bound form with the serum proteins. This was not in the scope of the study, but future work in this direction may shed light on phospholipid-serum protein interactions in raw bovine milk.

\section{CONCLUSIONS}

Contrary to the belief that only whole milk is a significant source of fat-soluble phospholipids, $31 \%$ of the total SM and $23 \%$ of the total PC present in whole raw milk (i.e., 40 and $23 \mathrm{mg} / \mathrm{L}$, respectively) were found in late-lactation skim milk. The results in the current study also support the hypothesis that the casein micelles are carriers for the lipophilic choline metabolites SM and PC appearing in bovine skim milk. Approximately 35 to $46 \%$ of dominating SM candidates and 22 to $29 \%$ of dominating PC candidates found in raw skim milk were found associated with the casein proteins. The largest casein micelles (diameter $=149$ $\mathrm{nm}$ ) in late lactation were found to be associated with maximum concentrations of SM d18:1/22:0 $(343.1 \mu \mathrm{g} / \mathrm{g}$ of casein protein) and PC 16:0/18:1 $(180.2 \mu \mathrm{g} / \mathrm{g}$ of casein protein). Whether the association between casein micelles and PC-SM results only from the attrition of the fat globule membrane during processing or during formation in the mammary gland remains to be elucidated. The current study demonstrates that the casein micelles in commercial skim milk powder are potential carriers of SM and PC for the fortification of infant formulas or low-fat dairy products with relevant bioactive compounds.

\section{ACKNOWLEDGMENTS}

We acknowledge Nadine Houck from The Pennsylvania State University Dairy Barns (University Park) for playing a key role in this study by providing access to the animals in specific lactation stages and helping with the collection of raw milk samples. We acknowledge the Metabolomics Core Facility at The Pennsylvania State University for performing liquid chromatography-tandem MS analysis supported by grant NSF MRI 1126373. We acknowledge the contributions of Maneesha Mohan in providing her expertise and helpful suggestions in optimizing size exclusion chromatography for the separation of casein micelles. This work was 
supported by the USDA National Institute of Food and Agriculture (Washington, DC) Federal Appropriations under project PEN04565 and accession no. 1002916.

\section{REFERENCES}

Artegoitia, V. M., J. L. Middleton, F. M. Harte, S. R. Campagna, and M. J. De Veth. 2014. Choline and choline metabolite patterns and associations in blood and milk during lactation in dairy cows. PLoS One 9:e103412. https://doi.org/10.1371/journal.pone .0103412 .

Bitman, J., and D. L. Wood. 1990. Changes in milk fat phospholipids during lactation. J. Dairy Sci. 73:1208-1216. https://doi.org/10 .3168/jds.S0022-0302(90)78784-X.

Bligh, E. G., and W. Dyer. 1959. A rapid method of total lipid extraction and purification. Can. J. Biochem. Physiol. 37:911-917. https: //doi.org/10.1139/o59-099.

Bourassa, P., L. Bekale, and H. A. Tajmir-Riahi. 2014. Association of lipids with milk $\alpha$ - and $\beta$-caseins. Int. J. Biol. Macromol. 70:156166. https://doi.org/10.1016/j.ijbiomac.2014.06.038.

Bradford, M. M. 1976. A rapid and sensitive method for the quantitation of microgram quantities of protein utilizing the principle of protein-dye binding. Anal. Biochem. 72:248-254. https://doi.org/ 10.1016/0003-2697(76)90527-3.

Caro, A. L., M. R. Rodríguez Niño, and J. M. Rodríguez Patino. 2009. Dynamics of penetration of dipalmitoyl-phosphatidyl-choline (DPPC) monolayers by $\beta$-casein. Colloids Surfaces A Physicochem. Eng. Asp. 341:134-141. https://doi.org/10.1016/j.colsurfa .2009.03.056

Caro, A. L., A. R. Mackie, A. P. Gunning, P. J. Wilde, V. J. Morris, M. R. Rodríguez Niño, and J. M. Rodríguez Patino. 2007. Role of electrostatic interactions on molecular self-assembly of protein plus phospholipid films at the air-water interface. Pages 227-243 in Food Colloids: Self-Assembly and Material Science. E. Dickinson and M. E. Leser, ed. Royal Society of Chemistry, London, UK.

Caudill, M. A. 2010. Pre- and postnatal health: Evidence of increased choline needs. J. Am. Diet. Assoc. 110:1198-1206. https://doi.org/ 10.1016/j.jada.2010.05.009.

Cheema, M., M. S. Mohan, S. R. Campagna, J. L. Jurat-Fuentes, and F. M. Harte. 2015. The association of low-molecular-weight hydrophobic compounds with native casein micelles in bovine milk. J. Dairy Sci. 98:5155-5163. https://doi.org/10.3168/jds.2015-9461.

Christie, W. W., R. C. Noble, and G. Davies. 1987. Phospholipids in milk and dairy products. Int. J. Dairy Technol. 40:10-12. https:// doi.org/10.1111/j.1471-0307.1987.tb02385.x.

Claumarchirant, L., A. Cilla, E. Matencio, L. M. Sanchez-Siles, P. Castro-Gomez, J. Fontecha, A. Alegra, and M. J. Lagarda. 2016. Addition of milk fat globule membrane as an ingredient of infant formulas for resembling the polar lipids of human milk. Int. Dairy J. 61:228-238. https://doi.org/10.1016/j.idairyj.2016.06.005.

Contarini, G., and M. Povolo. 2013. Phospholipids in milk fat: Composition, biological and technological significance, and analytical strategies. Int. J. Mol. Sci. 14:2808-2831. https://doi.org/10.3390/ ijms14022808.

Dalgleish, D. G. 2011. On the structural models of bovine casein micelles - Review and possible improvements. Soft Matter 7:22652272. https://doi.org/10.1039/C0SM00806K.

Dalgleish, D. G., D. S. Horne, and A. J. R. Law. 1989. Size related differences in bovine casein micelles. Biochim. Biophys. Acta 991:383-387. https://doi.org/10.1016/0304-4165(89)90061-5.

de Kruif, C. G., T. Huppertz, V. S. Urban, and A. V. Petukhov. 2012. Casein micelles and their internal structure. Adv. Colloid Interface Sci. 171-172:36-52. https://doi.org/10.1016/j.cis.2012.01.002.

Donato, P., F. Cacciola, F. Cichello, M. Russo, P. Dugo, and L. Mondello. 2011. Determination of phospholipids in milk samples by means of hydrophilic interaction liquid chromatography coupled to evaporative light scattering and mass spectrometry detection. J. Chromatogr. A 1218:6476-6482. https://doi.org/10.1016/j.chroma .2011.07.036.
Donnelly, W. J., G. P. McNeill, W. Buchheim, and T. C. A. McGann. 1984. A comprehensive study of the relationship between size and protein composition in natural casein micelles. Biochim. Biophys. Acta 789:136-143. https://doi.org/10.1016/0167-4838(84)90197-3.

Farrell, H. M., R. Jimenez-Flores, G. T. Bleck, E. M. Brown, J. E. Butler, L. K. Creamer, C. L. Hicks, C. M. Hollar, K. F. Ng-KwaiHang, and H. E. Swaisgood. 2004. Nomenclature of the proteins of cows' milk - Sixth revision. J. Dairy Sci. 87:1641-1674. https://doi .org/10.3168/jds.S0022-0302(04)73319-6.

Fong, B. Y., C. S. Norris, and A. K. H. MacGibbon. 2007. Protein and lipid composition of bovine milk-fat-globule membrane. Int. Dairy J. 17:275-288. https://doi.org/10.1016/j.idairyj.2006.05.004.

Gallier, S.. D. Gragson, R. Jiménez-Flores, and D. W. Everett. 2012 $\beta$-Casein-phospholipid monolayers as model systems to understand lipid-protein interactions in the milk fat globule membrane. Int. Dairy J. 22:58-65. https://doi.org/10.1016/j.idairyj.2011.08.007.

Garcia, C., N. W. Lutz, S. Confort-Gouny, P. J. Cozzone, M. Armand, and M. Bernard. 2012. Phospholipid fingerprints of milk from different mammalians determined by 31P NMR: Towards specific interest in human health. Food Chem. 135:1777-1783. https://doi .org/10.1016/j.foodchem.2012.05.111.

Graves, E. L. F., A. D. Beaulieu, and J. K. Drackley. 2007. Factors affecting the concentration of sphingomyelin in bovine milk. J. Dairy Sci. 90:706-715. https://doi.org/10.3168/jds.S0022-0302(07)71554 -0 .

Holmes-McNary, M. Q., W. L. Cheng, M. H. Mar, S. Fussel, and S. H. Zeisal. 1996. Choline and choline esters in human and rat milk and in infant formulas. Am. J. Clin. Nutr. 64:572-576. https://doi.org/ 10.1093/ajcn/64.4.572.

Holt, C., J. A. Carver, H. Ecroyd, and D. C. Thorn. 2013. Invited review: Caseins and the casein micelle: Their biological functions, structures, and behavior in foods. J. Dairy Sci. 96:6127-6146. https://doi.org/10.3168/jds.2013-6831.

Hsu, F. F., and J. Turk. 2000. Structural determination of sphingomyelin by tandem mass spectrometry with electrospray ionization. J. Am. Soc. Mass Spectrom. 11:437-449. https://doi.org/10.1016/ S1044-0305(99)00150-6.

Le Maux, S., S. Bouhallab, L. Giblin, A. Brodkorb, and T. Croguennec. 2014. Bovine $\beta$-lactoglobulin/fatty acid complexes: Binding, structural, and biological properties. Dairy Sci. Technol. 94:409426. https://doi.org/10.1007/s13594-014-0160-y.

Lopez, C., V. Briard-Bion, O. Ménard, E. Beaucher, F. Rousseau, J. Fauquant, N. Leconte, and B. Robert. 2011. Fat globules selected from whole milk according to their size: Different compositions and structure of the biomembrane, revealing sphingomyelin-rich domains. Food Chem. 125:355-368. https://doi.org/10.1016/j .foodchem.2010.09.005.

Lopez, C., V. Briard-Bion, O. Menard, F. Rousseau, P. Pradel, and J. M. Besle. 2008. Phospholipid, sphingolipid, and fatty acid compositions of the milk fat globule membrane are modified by diet. J. Agric. Food Chem. 56:5226-5236. https://doi.org/10.1021/ jf7036104.

Mandalari, G., A. M. Mackie, N. M. Rigby, M. S. J. Wickham, and E. N. C. Mills. 2009. Physiological phosphatidylcholine protects bovine $\beta$-lactoglobulin from simulated gastrointestinal proteolysis. Mol. Nutr. Food Res. 53:S131-S139. https://doi.org/10.1002/mnfr .200800321 .

Martins, P. A. T., F. Gomes, W. L. C. Vaz, and M. J. Moreno. 2008. Binding of phospholipids to $\beta$-lactoglobulin and their transfer to lipid bilayers. Biochim. Biophys. Acta Biomembr. 1778:1308-1315. https://doi.org/10.1016/j.bbamem.2008.02.011.

Mohan, M. S., J. L. Jurat-Fuentes, and F. Harte. 2013. Binding of vitamin A by casein micelles in commercial skim milk. J. Dairy Sci. 96:790-798. https://doi.org/10.3168/jds.2012-5777.

Ostersen, S., J. Foldager, and J. E. Hermansen. 1997. Effects of stage of lactation, milk protein genotype and body condition at calving on protein composition and renneting properties of bovine milk. J. Dairy Res. 64:207-219.

Puyol, P., M. D. Perez, J. Manuel, and M. Calyo. 1991. Interaction of bovine $\beta$-lactoglobulin and other bovine human whey proteins 
with retinol and fatty acids. Agric. Biol. Chem. 55:2515-2520. https://doi.org/10.1080/00021369.1991.10871001.

Roach, A., J. Dunlap, and F. Harte. 2009. Association of triclosan to casein proteins through solvent-mediated high-pressure homogenization. J. Food Sci. 74:N23-N29. https://doi.org/10.1111/j.1750 $-3841.2009 .01048 . x$.

Rodríguez Niño, M. R. R., A. L. Caro, and J. M. R. Patino. 2009. Structural, topographical, and rheological characteristics of $\beta$-casein-dioleoyl phosphatidylcholine (DOPC) mixed monolayers. Colloids Surf. B Biointerfaces 69:15-25. https://doi.org/10.1016/j colsurfb.2008.10.010

Rombaut, R., J. Van Camp, and K. Dewettinck. 2006. Phospho- and sphingolipid distribution during processing of milk, butter and whey. Int. J. Food Sci. Technol. 41:435-443. https://doi.org/10 $.1111 / j .1365-2621.2005 .01091 . x$.

Sahu, A., N. Kasoju, and U. Bora. 2008. Fluorescence study of the curcumin-casein micelle complexation and its application as a drug nanocarrier to cancer cells. Biomacromolecules 9:2905-2912. https://doi.org/10.1021/bm800683f.

Sala-Vila, A., A. I. Castellote, M. Rodriguez-Palmero, C. Campoy, and M. C. López-Sabater. 2005. Lipid composition in human breast milk from Granada (Spain): Changes during lactation. Nutrition 21:467-473.

Sánchez-Juanes, F., J. M. Alonso, L. Zancada, and P. Hueso. 2009 Distribution and fatty acid content of phospholipids from bovine milk and bovine milk fat globule membranes. Int. Dairy J. 19:273278. https://doi.org/10.1016/j.idairyj.2008.11.006.

Semo, E., E. Kesselman, D. Danino, and Y. D. Livney. 2007. Casein micelle as a natural nano-capsular vehicle for nutraceuticals. Food Hydrocoll. 21:936-942. https://doi.org/10.1016/j.foodhyd.2006.09 .006 .

Shapira, A., Y. G. Assaraf, and Y. D. Livney. 2010a. Beta-casein nanovehicles for oral delivery of chemotherapeutic drugs. Nanomedicine 6:119-126.

Shapira, A., G. Markman, Y. G. Assaraf, and Y. D. Livney. 2010b. $\beta$-casein-based nanovehicles for oral delivery of chemotherapeutic drugs: Drug-protein interactions and mitoxantrone loading capacity. Nanomedicine 6:547-555. https://doi.org/10.1016/j.nano.2010 .01 .003 .
Tanaka, K., M. Hosozawa, N. Kudo, N. Yoshikawa, K. Hisata, H. Shoji, K. Shinohara, and T. Shimizu. 2013. The pilot study: Sphingomyelin-fortified milk has a positive association with the neurobehavioural development of very low birth weight infants during infancy, randomized control trial. Brain Dev. 35:45-52. https://doi .org/10.1016/j.braindev.2012.03.004.

Timby, N., M. Domellöf, B. Lönnerdal, and O. Hernell. 2017. Supplementation of infant formula with bovine milk fat globule membranes. Adv. Nutr. 8:351-355. https://doi.org/10.3945/an.116 .014142 .

Trejo, R.. T. Dokland, J. Jurat-Fuentes, and F. Harte. 2011. Cryotransmission electron tomography of native casein micelles from bovine milk. J. Dairy Sci. 94:5770-5775. https://doi.org/10.3168/ jds.2011-4368

Zeisel, S. H., M.-H. Mar, J. C. Howe, and J. M. Holden. 2003. Concentrations of choline-containing compounds and betaine in common foods. J. Nutr. 133:1302-1307. https://doi.org/10.1093/jn/133.5 1302.

Zhao, Y.-Y., Y. Xiong, and J. M. Curtis. 2011. Measurement of phospholipids by hydrophilic interaction liquid chromatography coupled to tandem mass spectrometry: The determination of choline containing compounds in foods. J. Chromatogr. A 1218:5470-5479. https://doi.org/10.1016/j.chroma.2011.06.025.

Zheng, H., R. Jiménez-Flores, and D. W. Everett. 2014. Lateral lipid organization of the bovine milk fat globule membrane is revealed by washing processes. J. Dairy Sci. 97:5964-5974. https://doi.org/ 10.3168/jds.2014-7951.

Zimet, P., and Y. D. Livney. 2009. Beta-lactoglobulin and its nanocomplexes with pectin as vehicles for $\beta-3$ polyunsaturated fatty acids. Food Hydrocoll. 23:1120-1126. https://doi.org/10.1016/j foodhyd.2008.10.008.

Zimet, P., D. Rosenberg, and Y. D. Livney. 2011. Re-assembled casein micelles and casein nanoparticles as nano-vehicles for omega-3 polyunsaturated fatty acids. Food Hydrocoll. 25:1270-1276. https: //doi.org/10.1016/j.foodhyd.2010.11.025.

Zou, X., Z. Guo, Q. Jin, J. Huang, L. Cheong, X. Xu, and X. Wang. 2015. Composition and microstructure of colostrum and mature bovine milk fat globule membrane. Food Chem. 185:362-370. https://doi.org/10.1016/j.foodchem.2015.03.145. 